\title{
LA IMAGEN DEL JUDÍO EN EL CINE ESPAÑOL
}

The Image of the Jews in the Spanish Cinema

\author{
ASHER SALAH ${ }^{\mathrm{a}}$ \\ Bezalel Academy of Arts \& Design, Jerusalem \\ Hebrew University, Jerusalem
}

DOI: http://dx.doi.org/10.15366/secuencias2017.46.004

\section{RESUMEN}

El siglo xx se ha caracterizado por el surgimiento de un nuevo interés en el relevante papel que el judaísmo ibérico ha desempeñado en la historia. Tras el descubrimiento de las comunidades cripto-judias en Portugal, el fenómeno converso y la diáspora sefardí han llamado mucho la atención, tanto a nivel de la investigación académica como de la opinión pública. Esto ha resultado en la formación de diferentes estereotipos sobre el «carácter» del judío ibérico o en lo que toca a la «singularidad» de la historia judía peninsular. Aun cuando la exactitud no es imprescindible en la representación cinematográfica de los acontecimientos históricos, las películas constituyen una fuente inestimable para comprender este aspecto particular del imaginario colectivo. Sin embargo, con la destacada pero obsoleta excepción de Rafael de España (1991) y a un puñado de referencias a judíos en ensayos sobre la etnicidad y el antisemitismo en el cine iberoamericano, la imagen de los judíos y del judaísmo en el cine español no ha sido objeto de ningún estudio específico. Este artículo se propone analizar diacrónicamente algunas de las imágenes más comunes sobre la experiencia judía en España, entre las cuales destaca la fascinación del Séptimo Arte por la historia y las leyendas de la Inquisición, que representan casi un sub-género cinematográfico en sí mismo. El corpus examinado incluye cuarenta y seis largometrajes de ficción que tratan de la presencia de personajes judíos en el cine español de 1915 hasta hoy.

Palabras clave: judíos en el cine, cine español, Inquisición, «marranos», antisemitismo, historia judía en la península ibérica, estereotipos étnicos.

\section{ABSTRACT}

The history of Iberian Jews has aroused extraordinary interest in the twentieth century. After the discovery of the last Crypto-Jewish communities in Portugal, considerable attention has been paid to the Converso phenomenon and the Sephardi Diaspora, both in academia and in the public eye. This has resulted in the formation of different stereotypes concerning the «character» of the Iberian Jew or the «singularity» of Jewish history in the peninsula. While historical accuracy is usually not at stake in cinematic representations of events, films are a valuable source for understanding this particular aspect of the collective imaginary. Despite the valuable but outdated essay by Rafael de España (1991), and the scattered references concerning Jewish ethnicity, or the in works on anti-Semitism in Ibero-American cinema, the image of Jews and Judaism in Spanish cinema has not received specific attention. In this paper, I would like to analyse the evolution of some of most prevalent images of the Jewish experience in Spain. I will highlight the fascination of the seventh art for the Inquisition's history and legends, which represents almost a subgenre of historical films. The cinematic corpus, consisting of forty-six feature films, concerns the presence of Jewish characters in Spanish cinema and covers the period from 1915 to today.

Keywords: Jews in motion pictures, Spanish cinema, Inquisition, «marranos», antisemitism, Jewish history in the Iberian Peninsula, ethnic stereotypes.

[a] Asher Salah es profesor de Historia y Filosofía en el departamento de Historia y Teoría de la Academia de Bellas Artes Bezalel y en la Universidad Hebrea de Jerusalén. Especializado en la historia de los judíos en Italia en la Edad Moderna, en la última década se ha ocupado también de la representación de los judíos en el cine del área mediterránea: Italia, Israel y España en particular. Asher Salah ha sido becario postdoctoral en los seminarios del Herbert D. Katz Center for Advanced Judaic Studies en la Universidad de Pennsylvania (2011-2012 y 2014-2015) y en el Maimonides Center for Advanced Studies in Jewish Scepticism de la Universidad de Hamburgo (2016-2017). E-mail: oriash@013.net. 
A pesar de que la productividad discursiva sobre la alteridad en el cine viene avalada por una larga tradición de estudios también de área hispánica ${ }^{1}$, la imagen de los judíos y del judaísmo en el cine español no ha sido objeto de ningún estudio específico, con la única excepción del breve ensayo publicado por Rafael de España hace veinticinco años, preocupado sobre todo por averiguar la presencia de estereotipos de carácter antisemita en las pantallas nacionales ${ }^{2}$. Por lo tanto, podríamos estar tentados de desatender la cuestión, dando por sentado, como apunta Isabel Santaolalla, que «lo judío ha tenido, y tiene, una escasísima presencia en el cine español»3.

Sin embargo, es lícito dudar de la exactitud de tan contundente aserción. Disponiendo en abundancia de repertorios y catálogos de películas, además de sofisticados instrumentos de búsqueda en internet, es posible a la hora actual recoger muchos más datos y con mayor exhaustividad de lo que alcanzaba anteriormente a un buen investigador sobre el conjunto de la producción cinematográfica española en torno a una figura tan elusiva, a menudo casi invisible a una mirada desprevenida, como puede ser la del judío.

\section{Cuestiones de método}

Este estudio se basa en un corpus de cuarenta y seis largometrajes de ficción, producidos en España por directores españoles, que contienen referencias a temáticas judías, halladas de la manera más inclusiva posible y acogiendo tanto personajes aislados y referencias adventicias como episodios que forman parte esencial de la intriga. No me ocuparé, por lo tanto, ni de documentales -que se van a citar excepcionalmente cuando resulten particularmente pertinentes al asunto tratado- ni de películas internacionales que se inspiran en personajes o momentos de la historia judía de la península ibérica.

Quedan, asimismo, fuera de mi muestra cinematográfica, los quehaceres televisivos, sitcoms y telenovelas, a pesar de las justas advertencias de Paul Julian Smith, quien considera que los largometrajes de cine no son suficientemente representativos de la totalidad del campo audiovisual de un país como España 4 . Aunque la ficción televisiva se configura siempre más como una de las principales formas de narrativa nacional española y ha llegado a ser un fórum privilegiado para elaborar o debatir cuestiones como la etnia y la inmigración, no solo es que mi cultura audiovisual no alcance tanto como para examinar esta impresionante cantidad de material, sino que también resulta que, con la excepción del retrato del establecimiento del tribunal del Santo Oficio y la expulsión de los judíos en la segunda temporada (2013) de la serie Isabel de RTVE y una imagen de una inscripción en hebreo al revés en El águila roja (RTVE: 2009-2016), únicamente la serie emitida por la televisión vasca a partir de 2005, Mi querido Klikowsky, presenta un protagonista claramente identificable como judío.

No es tampoco mi intención tratar el papel de los judíos en la industria cinematográfica española, sobre todo de los alemanes y originarios de Europa
[1] Pienso en particular en los trabajos de Isabel Santaolalla, Los otros: etnicidad y raza en el cine español (Zaragoza, Prensas Universitarias de Zaragoza, 2005), Katarzyna Olga Beilin, Del infierno al cuerpo, la otredad en la narrativa $y$ en el cine español contemporáneo (Madrid, Ediciones Libertarias, 2007) y el volumen de Nancy Berthier y Jean-Claude Seguin (eds.), Cine, nación y nacionalidades en España (Madrid, Casa de Velázquez, 2007).

[2] Rafael de España, "Antisemitismo en el cine español» (Film-Historia, $\mathrm{n}^{\mathrm{o}}$ 1,2 1991), pp. 89-102. A este se podrían añadir estudios dedicados a películas particulares como el de Tzvi Tal, «Seres queridos y objetos étnicos: judíos y palestinos en la comedia cinematográfica española», en España y Israel: veinte años después (Madrid, Librería-Editorial Dykinson, 2007), pp. 215-223, y otras obras en las que incidentalmente se discute de aspectos de interés judío en algunos filmes, como las que mencionaremos en este artículo.

[3] Isabel Santaolalla, Los otros: etnicidad y raza en el cine español, p. 47.

[4] Paul Julian Smith, «Representando a los otros: el cine y la televisión contemporánea», en España e Israel: veinte años después (Madrid, Librería-Editorial Dykinson, 2007), p. 319. 


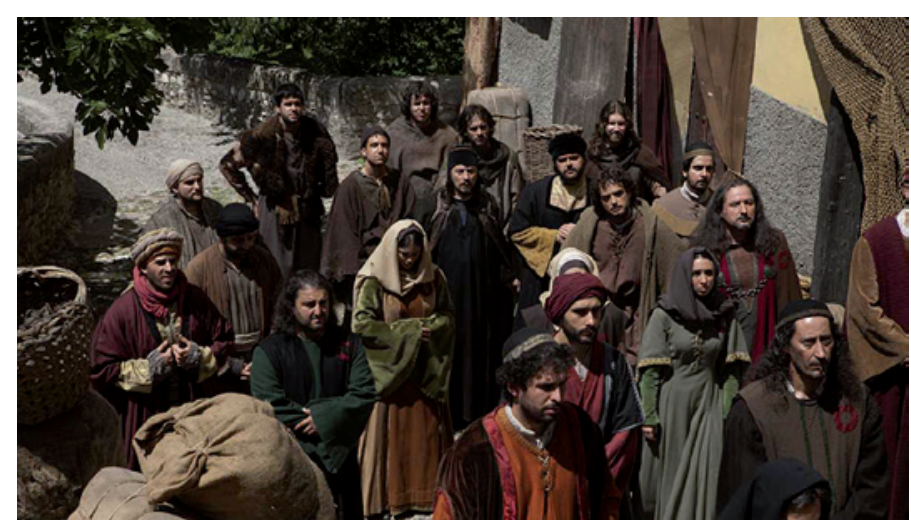

Fotograma del capítulo «La expulsión de los judíos» en la serie Isabel (RTVE: 2012-2014) del Este afincados en España o en Portugal a partir de los años treinta $^{5}$. Baste recordar aquí la importante contribución al cine español de: cineastas como el húngaro Ladislao Vajda (19061965) ${ }^{6}$; el alemán Max Nosseck (1902-1972), quien trabajó para la Ibérica film (fundada por otro judío polaco, David Oliver [18801947], activa entre 1933 y 1936, periodo en el cual produjo tres películas en la España republicana) $)^{7}$ y los argentinos Leon
[5] Fernando González García, «Exiliados judíos del Tercer Reich en el cine español: 1933-1936» (Secuencias, nº 37, 2013), pp. 9-33.

[6] Valeria Camporesi, «Para una historia de lo no nacional en el cine español. Ladislao Vajda y el caso de los huidos de las persecuciones antisemitas en España», en Cine, nación y nacionalidades, Nancy Berthier \& J.C. Seguin (eds.), (Madrid, Casa de Velázquez, 2007), pp. 61-74.

[7] Fernando González García y Valeria Camporesi, «Un progreso en el arte nacional. Ibérica films en España, 1934-1936» (BSAA arte, $\left.\mathrm{n}^{\circ} 77,2011\right)$, pp. 265-286.
Klimovsky (1906-1996) y Luis Saslavsky (1903-1995); además de decoradores como Pierre Schild (1892-196?) y Herbert Lippschitz (1904-1972); del director de fotografía Enrique Guerner (1895-1962), alias Heinrich Gärtner; de Wilhelm (Guillermo o Willy) Goldberger, operador de Edgar Neville entre 1935 y 1941, y de su hermano Issy (Isidor) ${ }^{9}$; de Fred Mandel, camarógrafo activo entre el 1934 y el 1940 ${ }^{10}$; o de productores como Geza Pollatschick, Erich Darmstaedler (que fundaron la Inca Film en Barcelona en los primeros años treinta), Sergio Newman Zack (1914-2006), paraguayo de origen ruso, Samuel Bronston (quien adquirió en 1963 los estudios de Chamartín fundados en 1941) ${ }^{11}$; y hasta los refugiados de dictaduras latinoamericanas, sobre todo argentinos como los actores Cecilia Roth, Adolfo Weitzmann, Rodolfo Kuhn o Norman Brisky ${ }^{12}$. La identidad judía de estos artistas y autores no parece haber tenido demasiada influencia en sus obras y carreras, a pesar de que en un caso, Ladislao Vajda, director de Marcelino pan y vino en 1955, consiguió eliminar algunas alusiones a los ju-

[8] Sobre Guerner y su escuela véase Francisco Llinas (coord.), Directores de fotografía del cine español (Madrid, Filmoteca española, 1989) y Vicente Sanchez-Biosca, «Photography, Production Design, and Editing», en Jo Labanyi y Tatiana Pavlovic (eds.), A Companion to Spanish Cinema, (London Blackwell, 2013), pp. 345-369.

[9] Sobre los hermanos Goldberger llegados a España en 1935 después de una breve estancia en Holanda, véase José Luis Borau (dir.), Diccionario del cine español (Madrid, Alianza Editorial, 1998), pp. 415-416.

[10] Sobre Mandel, ver también Roman Gubern, «Benito Perojo’s La Verbena de la Paloma», en Jenaro Talens y Santos Zunzunegui (eds.), Modes of Representations in Spanish Cinema (Minneapolis, University of Minnesota Press, 1998), p. 55.

[11] Jesús García de Dueñas, «Samuel Bronston. Ascenso y caída de un imperio», en Laura Gómez Vaquero y Daniel Sánchez Salas (eds.), El espíritu del caos: representación y recepción de las imágenes durante el franquismo (Madrid, Ocho y medio, 2009), pp. 435-473; Jesús García de Dueñas, El imperio Bronston (Madrid, El Imán, 2000), p. 233. La película La reina de España, de Fernando Trueba, de 2016, está ambientada en la época de oro de los estudios de Chamartín y el personaje judío de Sam Spiegelman (Arturo Ripstein) se inspira en productores norteamericanos que venían a España a rodar grandes reconstrucciones históricas.

[12] Sobre los extranjeros en general en el cine español, véase José Luis Borau (dir.), Diccionario del cine español, p. 336 y Bernard P. E. Bentley, A Companion to Spanish Cinema (Woodbridge, Tamesis, 2008), pp. 61-63. 
díos como pueblo deicida en el guion original ${ }^{13}$. Contrariamente al fenómeno de self-representation que se destaca en otras cinematografías internacionales de las últimas décadas, incluso en Latinoamérica ${ }^{14}$, por parte de jóvenes directores judíos, la pequeña comunidad judía en España no parece haber contribuido de manera significativa a su propia representación en la gran pantalla. La única película que retrata a una familia judía madrileña, cuya hija mayor tiene un novio palestino, realizada en España por autores judíos, es Seres queridos (2004) de la pareja anglo-catalana Dominic Harari y Teresa de Pelegrí.

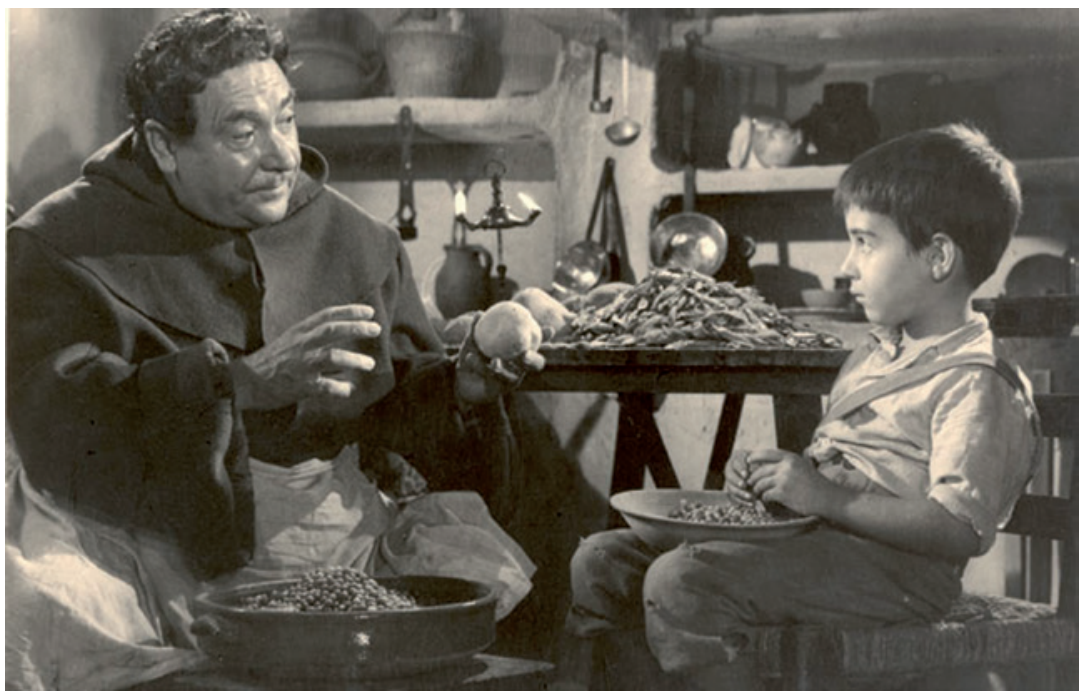

Fotograma de Marcelino, pan y vino (Ladislao Vajda, 1955).

Pero antes de abordar nuestro asunto, algunas premisas de carácter metodológico son ineludibles. Somos conscientes de la dificultad de definir qué es una película de interés judío y a qué corresponde la «hispanidad» del cine español: ¿es la ciudadanía del director?, ḋla proveniencia del presupuesto de la película?, ¿el tema tratado? ¿Y cómo abordar la creación artística realizada en las comunidades autónomas? Además, Nicholas Mirzroeff, el prócer de los visual culture studies, nos alerta sobre el problema intrínseco a la representación de fenómenos eminentemente transnacionales, como lo son los que conciernen al cine y al judaísmo, en un contexto donde la nación continúa siendo el sujeto primario de nuestras reflexiones culturales ${ }^{15}$. Además, como bien apunta Santaolalla:

el acto mismo de dar visibilidad a un grupo, de producir conocimiento acerca de él, tiene la potencialidad de generar todo tipo de efectos, desde los más enriquecedores hasta los más discriminatorios ${ }^{16}$.

La irrepresentabilidad de las diásporas encierra un problema particularmente grave al enfrentarse a la cuestión de la imagen de la diáspora judía y, en
[13] Veáse Valeria Camporesi, «Para una historia de lo no nacional», p. 66. En algunos casos, como el de Vajda con su Marcelino pan y vino o como el de Leon Klimovsky con su Aquella joven vestida de blanco (1954), biopic de Bernadette Soubirous, fueron judíos los autores de algunas de las obras más significativas del cine católico de la época.

[14] Carolina Rocha, «Jewish SelfRepresentations in Contemporary Argentine and Brazilian Films» (Journal of Modern Jewish Studies, $\left.\mathrm{n}^{\circ} 9-1,2010\right)$, pp. 37-48.

[15] Nicholas Mirzroeff (ed.), Diaspora and Visual Culture: Representing Africans and Jews (London, Routledge, 200o), p. 2.

[16] Isabel Santaolalla, Los otros: etnicidad y raza en el cine español, p.208. 
[17] Linda C. Ehrlich, "A Change of Scene, a Change of Fortune: Cinematic Visions of the Sephardic Jew» (Shofar: An Interdisciplinary Journal of Jewish Studies, 15, 2, Winter 1997), pp. 1-20.

[18] Citado en Luis Mariano González González, Fascismo Kitsch y cine histórico español (1939-1953) (Cuenca, Ediciones de la Universidad Castilla-La Mancha, 2009), p. 28.

[19] Tabea Linhard, Jewish Spain, a Mediterranean Memory (Stanford, Stanford University Press, 2014), p. 7. (La traducción es nuestra)

[20] Robert Salomon Wistrich, «La "otredad" judía en la historia europea: pasado y presente», en Silvina Shammah Gesser y Raanan Rein (coords.), El otro en la España contemporánea/Prácticas, discursos, representaciones (Sevilla, Anfora, 2011), pp. 55-82. particular, a la del sefardí en el cine, teniendo en cuenta sobre todo su historia plurisecular y sus complejas ramificaciones geográficas. ${ }^{17}$

Sin embargo, y con las debidas cautelas, para evitar, por ejemplo, una excesiva psicologización de las representaciones colectivas, creo que la perspectiva kracaueriana es todavía válida. Según esta: «las películas de una nación reflejan su mentalidad de forma más directa que otros medios artísticos por dos razones: nunca son el resultado de una obra individual e interesan a la multitud anónima» ${ }^{18}$.

Puesto que en esta fase de mi trabajo mi intención es ante todo explorar el conjunto de la producción cinematográfica realizada por directores de nacionalidad española, con el fin de juntar un corpus de films lo más amplio posible, he evitado a la postre cualquier definición esencialista y demasiado rígida de lo que hay que entender por judío y por ibérico.

Por esto, prefiero, de manera preliminar y en una perspectiva heurística abierta, ceñirme a la metáfora sugerida por Predrag Matvejevic y Tabea Linhard en su reciente obra de «mapas con bordes blandos y colores desteñidos ${ }^{19}$, para justificar el uso de términos ambiguos, como España y diáspora sefardí, sin tener necesariamente que localizar a estas entidades en un espacio y en un tiempo predefinidos. Esto tendría que evitar el riesgo de polarizar excesivamente la antinomia entre un «yo» inexistente contrapuesto a un «otro» igualmente indefinido, en el intento de matizar al mismo tiempo la noción de «hispanidad» y la de «judaísmo», de fijarse en las cuestiones irresueltas de la relación entre memoria e historia, entre individuo y colectividad, entre ideología e identidad, y de identificar líneas de continuidad o de ruptura, semejanzas generales o singularidades locales.

Finalmente, la última dificultad, que se tendrá que tener en cuenta, es que la representación de lo judío no puede ser separada de su posición en el interior de un debate más amplio que concierne la construcción (o la deconstrucción) de la identidad nacional en el cine y, por lo tanto, también con cuestiones relacionadas con la etnicidad, con fenómenos migratorios, con el colonialismo o con el lugar de la religión en la cultura contemporánea.

\section{Análisis del corpus cinematográfico}

No se puede decir que cuarenta y seis películas sean un número particularmente significativo en una cinematografía como la española, que ha producido hasta ahora alrededor de siete mil quinientos largometrajes de ficción. Contrariamente a lo que sostiene Wistrich, los judíos no parecen ser «el otro» por excelencia, por lo menos no en el cine español, como lo son y fueron para otras sociedades y culturas europeas ${ }^{20}$.

Esto aparece muy claramente, por ejemplo, comparando el tratamiento de la Inquisición en las películas españolas y en las extranjeras. De las veinticinco películas internacionales enfocadas en la persecución inquisitorial, dieciséis 
mencionan explícitamente a los judíos como su víctima principal ${ }^{21}$ mientras que, en el cine español, de las once películas que se refieren al tribunal del Santo Oficio, solo tres tratan oblicuamente sobre los judíos ${ }^{22}$, concentrándose las demás en el tema de la brujería ${ }^{23}$, muy a menudo con un fondo de voyerismo sexual y de «destape», como en la cinematografía de Jesús Franco o de Jacinto Molina ${ }^{24}$.

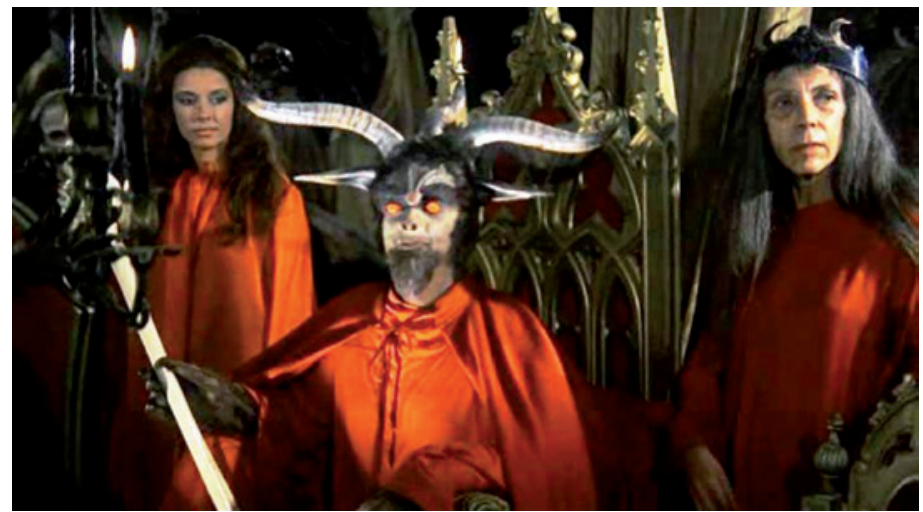

Fotograma de Inquisición (Jacinto Molina, 1978).

Otro ejemplo puede ser hallado en la casi total ausencia de «marranos» o judeo-conversos en las pantallas españolas ${ }^{25}$ mientras que, al otro lado de la frontera, es discernible un ávido interés precisamente por aquellas facetas de la historia ibérica, como el fenómeno del cripto-judaismo -de las que la historiografía nacional tardó mucho en percatarse y con sentimientos entremezclados ${ }^{26}$ - por parte de las películas francesas La Reina Margot (La Reine Margot, Patrice Chereau, 1994) o Rosa y negro (Rose et noir, Gerard Jugnot, 2009). Además, las representaciones históricas y estéticas del «marrano», bastante numerosas en el extranjero -pienso en particular en el film O Judeu, del brasileño Jom Tob Azulay de $1995^{27}$-, enfatizan la judeidad oculta del cristiano nuevo que la interrogación inquisitorial procura sacar a la luz en contraste con los rasgos aparentes que no lo distinguen en nada de los demás ciudadanos. En el cine español, por el contrario, el judío interesa por lo que tiene exteriormente de español más que por lo que tiene de judío, en secreto o no. Es emblemático el caso de La marrana (José Luis Cuerda, 1992), donde se estigmatizan los prejuicios que separan a cristianos y judíos a pesar de su común hispanidad.

[21] Giosue l'ebreo (Pascuale Scimeca, 2005), O Judeu (Jom Tob Azulay, 1995), HaYerushah (Amnon Rubinstein, 1993), Palabra y utopia (Palavra e Utopia, Manoel de Oliveira, 2000), O Convento (Manoel de Oliveira, 1995), La loca historia del mundo (History of the World: Part I, Mel Brooks, 1981), Los fantasmas de Goya (Goya's Ghosts, Milos Forman, 2006), 1492, La conquista del paraiso (1492: Conquest of Paradise, Riddley Scott, 1992), Cristobal Colón: el descubrimiento (Christopher Columbus: the Discovery, John Glen, 1992), El Santo Oficio (Arturo Ripstein, 1974), entre otros.

[22] La dama del armiño (Eusebio Fernández Ardavín, 1947), La portentosa vida del padre Vicente (Carles Mira, 1978), Alatriste (Agustín Díaz Yanes, 2006)

[23] Cartas de amor de una monja (Jorge Grau, 1978), Brujas mágicas (Mariano Ozores, 1981), El fraile (Francisco Lara Polop, 1990). La primera trata de un amor prohibido, las otras son biopics de El Greco. Véase también Maité Vienne, «La sorcière : une histoire d'intolérance» (Cinémaction, $n^{\circ}$ 92, 1999), pp. 48-54.

[24] Inquisición (Jacinto Molina, 1976), El sádico de Notre Dame (Jesús Franco, 1974).

[25] Solo la comedia de José Luis Cuerda del 1992, La marrana, lo hace. Sin embargo, el titulo se refiere a la cerda que se disputan los dos protagonistas, pícaros que cruzan las tierras de España en el año de la expulsión y se topan con judíos que se marchan del país o que prefirieron convertirse al cristianismo para quedarse. En La dama del armiño la confusión sobre la identidad religiosa del personaje del cristiano nuevo Samuel es constante y no se comprende que, siendo ya cristiano, al final de la película se bautice nuevamente.

[26] En lo que concierne a la historiografía española del siglo xix, ver Nitai Shinan, Qorbanot o Ashemim: Toledot Ha-Yehudim Be-Rei HaHistoriografia Ha-Sefaradit Ba-Shanim 1759-1898 (Víctimas o culpables: la historia de los judíos al espejo de la historiografía española en los años 1759-1898 (Jerusalem, 2011).

[27] Estudiada por Erin Graff Zivin, «Aporias of Marranismo: Sabina Berman's En el nombre de Dios and Jom Tob Azulay's O Judeu» (The New Centennial Review, $\mathrm{n}^{\circ}$ 12, 2012), pp. 187-216. 


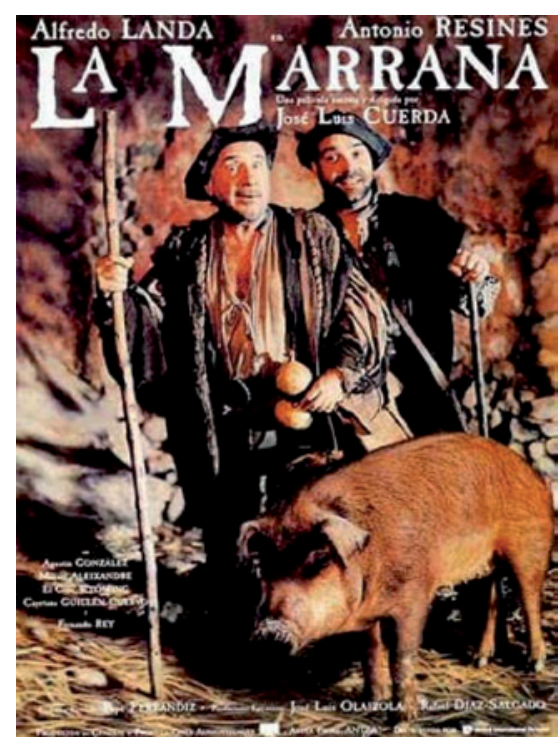

Cartel de La marrana (José Luis Cuerda, 1992).

La misma diferencia se podría detectar a propósito de la participación de voluntarios judíos en las brigadas internacionales (entre el 15 y el 20\% del total), cuya presencia en cuanto minoría étnica o religiosa entre los contingentes de varias nacionalidades pasa casi del todo desapercibida en el cine español, con la excepción del personaje de Berman (Mandy Patinkin) en La Reina de España (Fernando Trueba, 2016), excombatiente judío de la Brigada Lincoln, mientras que ha sido objeto de varios documentales en el extranjero $^{28}$. Tampoco el paso de entre veinte mil y treinta mil refugiados judíos por España durante la Segunda Guerra Mundial ha atraído la atención de la cinematografía tanto española como internacional, con la notable excepción de Walter Benjamin, a cuya muerte está dedicada $L a$ última frontera (Manuel Cussó-Ferrer, 1992), largometraje de ficción, aunque con aportaciones documentales, como la entrevista a Jean Selz, crítico de arte francés que conoció al filósofo alemán en Ibiza en los años treinta, o la voz en off de la fotógrafa Gisèle Freund ${ }^{29}$.

[28] Entre los más recientes, el israelí Madrid Before Hanita (Eran Torbiner, 2006), Hemingway \& Gellhorn (Philipp Kaufman, 2012). Sobre las representaciones en el cine de la historia de las brigadas internacionales, véase Magi Crusells, Las brigadas internacionales en la pantalla (Cuenca, Universidad Castilla-La Mancha, 2001). Sobre los judíos en las brigadas internacionales, véase

Arno Lustiger, iShalom libertad! Judíos en la Guerra Civil Española (Barcelona, Flor al viento, 2001); Gerben Zaagsma, Jewish Volunteers in the Spanish Civil War: A Case Study of the Botwin Company (Londres, University of London [tesis doctoral] 2001); Batia Donner y Rachel Bonfil (eds.), From Here to Madrid. Volunteers from Palestine in the International Brigades in Spain 1936-1938 (Tel Aviv, Eretz Israel Museum, 2012).

[29] A pesar de que sobre este tema existen importantes obras historiográficas, como los estudios fundamentales de Haim Avni, España, Franco y los judíos (Madrid, Altalena, 1982); Haim Avni, «España y Portugal, su actitud respecto de los refugiados judíos durante la era nazi», en Ignacio Klich y Mario Rapoport (coords.), Discriminación y racismo en América Latina (Buenos Aires, Nuevohacer, 1997), pp. 255-271; Antonio Marquina y Gloria Inés Ospina, España y los judíos en el siglo xx (Madrid, Espasa Calpe, 1987), pp. 159-232; Antonio Marquina, «La política del régimen de Franco hacia los sefarditas nacionalizados», en Ignacio Klich y Mario Rapoport (coords.), Discriminación y racismo, pp. 243-253; Bernd Rother, Franco y el Holocausto (Madrid, Marcial Pons, 2005); Josep Calvet, Les muntanyes de la llibertat. El pas d'evadits pels Pirineus durant la Segona Guerra Mundial 1939-1944 (Barcelona, La Magrana, 2008); «La repatriación de brigadistas alemanes», en Isabelle Rohr, The Spanish Right and the Jews (1898-1945): Antisemitism and Opportunism (Sussex, Sussex Academic Press, 2007), pp. 139-140.

[3o Véase Eva Woods Peiró, White Gypsies: Race and Stardom in Spanish Musical Films (Minneapolis, University of Minnesota Press, 2012).

[31] Véase Eloy Martín Corrales, La imagen del magrebí en España. Una perspectiva histórica (siglos XVI-Xx) (Barcelona, Bellatierra, 2002); Alberto Elena, La llamada de África, estudios sobre el cine colonial español (Barcelona, Bellatierra, 2010); Montserrat Bros Duran, La imagen del mundo árabe en el cine español (Barcelona, tesis doctoral, Universidad de Barcelona, 1990) y María Dolores Figares Romero de la Cruz, La colonización del imaginario: imágenes de África (Granada, UGR, 2003). También Ricard Zapata-Barrero, «La reproducción del “otro” musulmán en España a través de prácticas sociales y reacciones políticas», pp. 219-256. Sobre la presencia mucho mayor de personajes árabes en el cine español véase también las consideraciones expuestas por Montserrat Iglesias Santos, en «Representar al otro», Imágenes del otro. Identidad e inmigración en la literatura y el cine (Madrid, Biblioteca Nueva 2010), pp. 9-20. 
En efecto, a pesar de que cuarenta y seis películas constituían un conjunto de escasa entidad, sobre todo si pensamos en la importancia y visibilidad de temáticas judías en el cine norte y latinoamericano, francés, alemán y hasta en el italiano y sueco, países con pequeñas comunidades judías de un tamaño semejante a la española, se trata, de todas formas, de una cifra que permite sacar algunas conclusiones sobre un arco temporal bastante extendido.

\section{De la monarquía alfonsina a la Segunda República}

Del siguiente gráfico resultan algunas observaciones sobre un siglo de historia. Se empieza con Los cascabeles fantasmas (Ricard Baños, 1915), versión cinematográfica de la pieza teatral de Émile Erckmann (1822-1899) y Alexandre Chatrian (1826-1890) Le Juif polonais, obra que fue llevada varias veces a la gran pantalla en el cine europeo de los mismos años y que tendrá una segunda versión en 1920 firmada por el mismo director, para terminar con La espina de Dios, película española de tema religioso que narra los tres años de predicación de Jesús de Nazaret vistos desde la perspectiva de sus apóstoles en el contexto del judaísmo rabínico de la época, dirigida por Óscar Parra de Carrizosa, que se estrenó en 2015.

Respecto a los últimos años de la monarquía alfonsina, Los cascabeles fantasmas, un raro ejemplo de zarzuela con temática judía, a pesar de anticipar el interés que semejantes obras tendrán en Francia y en Europa en la década de los años veinte ${ }^{32}$, no nos deja deducir nada sobre su impacto en la cultura popular, sino que constata a través de esta excepción la casi absoluta ausencia de personajes judíos en general de las pantallas de la época.

Tampoco la Segunda República parece haber sido una temporada favorable para tópicos judíos, con la sola pero notable excepción de un documental de Ernesto Giménez Caballero (1899-1988), Judíos de Patria española (1931) ${ }^{33}$, y un drama histórico, Isabel de Solís, reina de Granada (José Buchs, 1931). En Isabel de Solís... aparecen fugazmente los personajes de Samuel, alquimista hebreo de Granada que prepara el brebaje para que la hermosa cautiva cristiana Isabel caiga en letargo y sea entregada al príncipe musulmán Mulay Hacem, y de la hija de Samuel, Noemí (Ketty Moreno), que se enamora del capitán cristiano Don Fernando de Vargas cuando este encuentra refugio en casa del judío después de haber logrado fugarse de las mazmorras de los moros que lo apresaron. A pesar de que la imagen del judío esté aquí asociada a sus artimañas mágicas y traicioneras, la de su hija se caracteriza por una instintiva generosidad hacia el caballero cristiano, según una estereotipia
[32] Dimitri Vezyroglou, «Une chose et son contraire : le cinéma français et les ambiguïtés du philosémitisme en 1925", en M.-A. Matard-Bonucci (ed.), ANTISÉmythes; l'image des juifs entre culture et politique, 1848-1939, (París, Nouveau Monde éditions, 2005), pp. 207-216.

[33] Es ejemplar el estudio que a esta película le ha dedicado Michal Friedman, «Reconquering 'Sepharad': Hispanism and Proto-Fascism in Giménez Caballero's Sephardist Crusade», en Daniela Flesler, Tabea Linhard, Adrián Pérez Melgosa (eds.), Revisiting Jewish Spain in the Modern Era (Londres, Routledge, 2013), pp. 35-6o. 
[34] Sobre las imágenes de judíos en la literatura inglesa véase Edgard Rosenberg, From Shylock to Svengali. Jewish Stereotypes in English Fiction (Stanford, Stanford University Press, 1960).

[35] Esto es lo que James Lastra sostiene refiriéndose a algunas entrevistas de Buñuel donde él dice haber pensado en los pobladores judíos de Las Hurdes y en la huella de su presencia que permanecería en negativo en el rito del chivo expiatorio practicado por la comunidad local. Jaime Lastra e Ivone Margulies, (eds.), «Why Is this Absurd Picture Here?», en Rites of Realism: Essays on Corporeal Cinema (Durham, Duke University Press, 2002), pp. 200-205.

[36] Un caso aparte es representado por las películas donde en el guion se habla explícitamente de judíos, pero no en la versión final del film, como en Raza y en Marcelino pan y vino. Otro caso es el de filmes en los que aparecen personajes de origen judío sin que esto sea mencionado o aparezca de manera explícita; pienso en Blanca Brisac de Trece Rosas (Emilio Martínez Lázaro, 2007), pero también en El último kamikaze de Jacinto Molina, de 1983 , donde apenas se nota que una de las asesinas internacionales lleva una estrella de David en el cuello.

[37] José Schreiberman, «El tema judío en la generación del 98», en Los judíos en la España contemporánea, historia y visiones, 1898-1998 (Cuenca, Universidad Castilla-La Mancha, 2000), pp. 61-74. bastante común de la mujer judía atraída por los valores cristianos que tiene sus raíces en la figura de Jessica, hija de Shylock, en el mercader de Venecia de Shakespeare, para llegar hasta Rebecca, hija de Isaac, enamorada de Ivanhoe, protagonista de la homónima novela de Walter Scott ${ }^{34}$. Cabe destacar que ambos personajes, el de Samuel y el de Noemí, están ausentes tanto en la novela de Emilio Castelar, El suspiro del moro, publicada en Madrid en 1886, como en la versión del mismo episodio histórico de Francisco Martínez de la Rosa, el Walter Scott castellano, publicada en 1844, en las cuales Buchs (1896-1973) libremente se inspira. Sin embargo, es interesante notar cierta corriente de simpatía hacia los judíos y el afán por resaltar la afinidad entre españoles y sefardíes, de quienes Castelar fue portavoz dentro del republicanismo español después de la revolución del 1868; este interés aparece medio siglo más tarde tanto en el trabajo de un autor como Giménez Caballero, que al realizar su película sobre las comunidades judías del mediterráneo ya había abrazado las teorías del fascismo italiano, como en el de José Buchs, en cuyo interés hacia los judíos en la Historia de España no fue quizás ajena la influencia que ejerció el pensamiento de Jacinto Benavente, de quien Buchs fue un estrecho colaborador y que en sus memorias alude a sus posibles y no comprobados orígenes hebreos.

Dos años después del viaje de Giménez Caballero hacia los limites orientales de la hispanidad en Oriente medio y en los Balcanes, que lo lleva al descubrimiento de los judíos que él apoda «de patria española» y a la realización de su homónimo documental, Buñuel emprende un viaje opuesto con el rodaje de Las Hurdes (1933), un proyecto cinematográfico que se propone revelar lo ajeno y lo desconocido que aún se encuentra en el interior mismo de España. Parece que el director aragonés eligió esas tierras extremeñas por haber sido antaño pobladas por bandidos y judíos que huían de la Inquisición, lo que daría todo otro sentido a las imágenes y a los comentarios sobre el chivo expiatorio que tanta importancia tienen en la película ${ }^{35}$. La palabra «judío», sin embargo, no aparece en ninguna parte de los veintisiete minutos que dura la cinta y, por lo tanto, no está incluida en nuestra reseña ${ }^{36}$.

La ausencia del tema judío en las primeras décadas del siglo veinte es asombrosa si se tiene en cuenta la importancia de este en la literatura que se suele agrupar bajo el rótulo de Generación del 9837. Por ejemplo, Galdós, noventayochista en su última época, se interesa por el tema judío desde los comienzos de su larga carrera ${ }^{38}$ y, así también, Blasco Ibáñez y Pío Baroja. Sin embargo, ninguna de las transposiciones cinematográficas de sus obras (una decena) incluye a las de temática judía ${ }^{39}$.

[38] Con el triunfo del liberalismo tras la muerte de Fernando VII, este filosemitismo liberal se expresó en libros como la Historia de los judíos de España (1847), de Adolfo de Castro, Estudios históricos, políticos y literarios sobre los judíos de España (1848), de José Amador de los Ríos, en varias novelas de Pérez Galdós (Gloria, 1877, Misericordia, 1897, Fortunata y Jacinta, Aita Tettauen, 1905) y en los discursos y escritos del político republicano Emilio Castelar.

[39] Luis Gómez Mesa, La literatura española en el cine nacional, 1907-1977 (Madrid, Filmoteca Nacional de España, 1978). 


\section{El franquismo: primera época (de 1939 a 1952)}

Si la cuestión judía en los años veinte y treinta parece ser en la conciencia española un tema cuanto menos marginal ${ }^{40}$, donde es frecuente el tono elusivo y ostentosa la resistencia intelectual al legado hispano árabe y judío (como en otro contexto acontece en la obra de Unamuno y Ortega y Gasset) ${ }^{41}$, en el establecimiento de la dictadura franquista desde el fin de la guerra civil hasta los primeros años de la posguerra, cambia radicalmente la situación. Entre 1940 y 1952 ocho películas presentan personajes judíos, casi todos en papeles protagonistas e invariablemente descritos con ensañamiento antise-

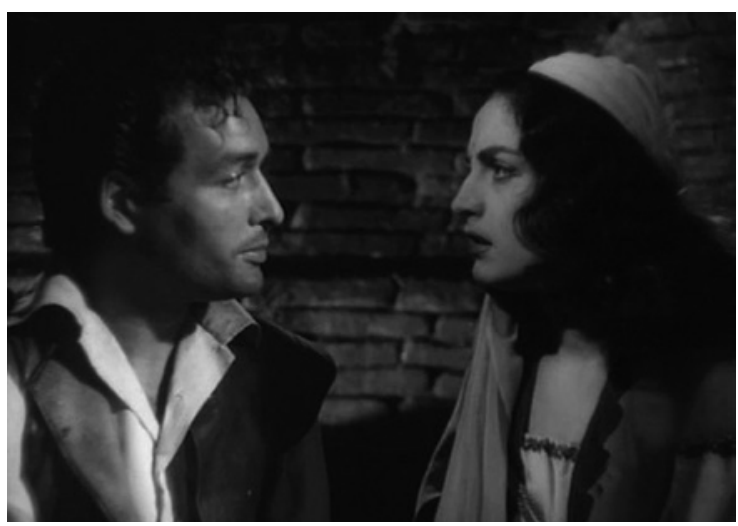

Jorge Mistral y Alicia Palacios en La dama del armiño (Eusebio Fernández Ardavín, 1947) mita, con la única y dudosa excepción de $L a$

dama del armiño (Eusebio Fernández Ardavín, 1947) ${ }^{42}$. En la misma, el personaje de Samuel Hebraim (Jorge Mistral), joven orfebre judío enamorado de la dama del armiño - que no es otra que Catalina, la hija del pintor El Greco, la cual le sirve de modelo para el célebre cuadro-, merece la compasión del público solo en el marco de su sincera conversión al catolicismo, demostrando una vez más que a veces hasta las raras posturas filosefardíes de la época parecen ser perfectamente compatibles con alusiones racistas ${ }^{43}$. Las películas de interés judío constituyen más del 2\% de las 587 cintas producidas entre 1940 y el 1952, un porcentaje jamás repetido, cuando el promedio de películas de fondo judío a lo largo del siglo oscila alrededor del 0,5\% de la producción total.

El dato es aún más sorprendente comparado con lo que sabemos de las cinematografías de dos países con regímenes políticos aliados al de España, como Italia, donde, a pesar de la promulgación de las leyes raciales en 1938 y las deportaciones de masa de judíos a partir de 1943, lo judío esta rigurosamente ausente de la gran pantalla ${ }^{44}$, o como Alemania donde, sobre un total de 1007 largometrajes realizados durante la época nazi, solo cuatro presen-
[40] A pesar de «diversas reapropiaciones memoriales y la valorización del pasado judío de los años 1930-40 (viII centenario de Maimónides en Córdoba), patrimonial (enriquecimiento de las colecciones museográficas) e incluso, como hemos visto, la creación de un instituto especializado en el CSIC», Danielle Rozenberg, L'Espagne contemporaine et la question juive (Toulouse, Presses Universitaires du Mirail, 2006), p. 269 (La traducción es nuestra).

[41] Jon Juaristi, «Las bases míticas comunes de las identidades españolas modernas», en El otro en la España contemporánea, pp. 375-403

[42] No obstante, según Rafael de España, aunque este film sea «el intento más atrevido de reconciliación racial» («Antisemitismo en el cine español» [Film-Historia, ${ }^{0}{ }^{1}$, 1991], pp.92), comparto la opinión más crítica y matizada de Fátima Gil Gascón (Españolas en un país de ficción. La mujer en el cine franquista [1939-1963] [Sevilla, Comunicación Social Ediciones, 2011], p. 178) cuando escribe a propósito de la representación de la mujer oriental: «las mujeres exóticas son también de moral disoluta. Jarifa, la morisca de la Dama del armiño, enamorada del judío Samuel, consiente en mantener relaciones sexuales con su carcelero a cambio de que este le permita verlo. Cuando le cuenta el hecho a Catalina, verdadera enamorada de Samuel, la chica se horroriza: Jarifa se halla en pecado mortal. “¿Qué te asusta? ¿Pues tú no lo harías, cristiana cobarde? Este era mi único talismán y yo lo utilicé”».

[43] Isabel Santaolalla «Los otros», p. 45 apunta que el actor Jorge Mistral «parecía atraer este tipo de personajes “raciales”, pues más adelante representaría al indígena Minoa en Misión blanca (Juan de Orduña, 1946) y al cacique guaraní Yapacacu en La manigua sin Dios (Arturo RuizCastillo, 1947)».

[44] Asher Salah, «Jews and Israel in Italian Cinema», en Italy 15oth Anniversary (Milano, Corriere della Sera Foundation, 2012), pp. 283301; Idem, «Maschere Giudaiche: gli ebrei al cinema italiano», en Italia Ebraica: oltre duemila anni di incontro tra la cultura italiana e l'ebraismo (Torino, Allemandi, 2007), pp. 221-235. 
[45] Las cuatro películas son Robert und Bertram (Hans Heinz Zerlett, 1939), Jud Süß (Veit Harlan, 1940), Die Rothschilds (Erich Waschneck, 1940) y Carl Peters (Herbert Selpin, 1941). Rafael de España escribe a propósito de estas películas: «De todos los films antisemitas producidos en el Reich, el único que tuvo auténtica difusión comercial fue Roberto $y$ Beltrán, y debemos advertir que la condición racial de los personajes "negativos" quedaba bastante imprecisa para el espectador español, sobre todo al tratarse de una comedia. La pièce de résistance del antisemitismo filmico, El judío Süß, tuvo algún pase semiprivado para personalidades, pero no queda constancia de que fuera distribuida comercialmente. De todos modos, en la prensa controlada por Falange se conocía (e indudablemente se apreciaba) el film, como revela un artículo aparecido en 1944 en la revista Primer Plano", "Antisemitismo en el cine español» (Film-Historia, $\mathrm{n}^{0} 1,2$ 1991), pp. 89.

[46] Véase Saturnino Rodríguez, El NO-DO: catecismo social de una época (Madrid, Editorial Complutense, 1999); Rafael R. Tranche y Vicente Sánchez-Biosca, No-Do. El tiempo y la memoria (Barcelona, Cátedra y Filmoteca española, 2001). En inglés también Sheelagh Ellwood, «The Moving Image of the Franco Regime: Noticiarios y Documentales (1939-1975)», en Helen Graham y Jo Labanyi (eds.), Spanish Cultural Studies (Oxford, Oxford University Press, 1995), pp. 201203. Ni siquiera en el noticiario que informa sobre la liberación de Buchenwald se habla de la identidad religiosa de la mayor parte de las víctimas. Véase $\mathrm{Sa}-$ turnino Rodríguez, p. 186. tan claras alusiones antisemitas ${ }^{45}$. Es posible que una de las razones de esta diferencia dependa del hecho de que, mientras en Alemania se trabajaba en movilizar a las masas para exterminar a los judíos reales y crear una imagen del mundo donde estos estuvieran ausentes, en España la escasa presencia de judíos en el territorio nacional permitía a un nivel imaginario enfrentarse con ideas abstractas relativas al judaísmo, a condición, por supuesto, de que esas pertenecieran a un pasado remoto y que sirvieran para poner en evidencia las virtudes de la hispanidad en contraste con todo lo que le era ajeno.

Esto explicaría, destacando la anómala situación española respecto al contexto alemán e italiano, por qué, mientras que el cine abunda en estereotipos antisemitas, brilla por su ausencia toda referencia a los judíos en otros órganos de propaganda del Estado, como en los documentales del No-Do ${ }^{46}$, contrariamente otra vez con respecto al nacional-socialismo alemán, que se sirvió intensamente de todos los canales de información oficial para difundir sus mensajes de odio racial ${ }^{47}$. Es cierto que un análisis más detenido tendría que tomar en cuenta las características de cada medio de adoctrinamiento del régimen, sus públicos y sus objetivos propios. Javier Domínguez-Arribas señala que:

Las alocuciones que versaban sobre las fechorías del enemigo judío y masónico, especialmente frecuentes durante la guerra civil, fueron difundidas a veces por radio, lo que permitía ampliar considerablemente su audiencia y, sobre todo, los periódicos. Las octavillas, por su parte, contenían a veces invectivas contra los masones y los judíos, acusados de dominar la España «roja»48.

Sin embargo, los datos aquí reunidos sobre el cine español en los años de la guerra mundial no corroboran enteramente, como hemos apenas visto, lo que escribe Arribas al apuntar que:

Diversos medios de propaganda contribuyeron a la difusión de las tesis antijudeo-masónicas entre 1936 y 1945. Dos medios visuales como los carteles o el cine no parecen haber desempeñado un rol capital, excepciones aparte, mientras que la propaganda oral - conferencias, discursos, arengas- permitió hacer llegar estas tesis a públicos muy distintos.

El cine fue, en realidad, bastante activo al tratar de manera explícita los temas del antijudaísmo tradicional ${ }^{49}$. Además, como señala Fernando González García, en las revistas cinematográficas más afines al régimen, por lo menos hasta 1943, la producción estadounidense es a menudo condenada en bloque en tanto que «cine hebreo» o punta de lanza de una supuesta «conspiración hebrea»50.

[47] Hay que mencionar sin embargo el documental División azul (Víctor de Serna y Joaquín Reig Gonzalbes, 1942) estudiado por Sergio Alegre Calero, «Las imágenes de la división azul; los vaivenes de la política exterior e interior de Franco a través del cine», en Aitor Yraola (co.), Historia contemporánea de España y cine (Madrid, Ediciones de la Universidad Autónoma, 1997), pp. 69-84.

[48] Javier Domínguez Arribas, El enemigo judeo-masónico en la propaganda franquista (1936-1945) (Madrid, Marcial Pons, 2010 ), p. 487.

[49] Román Gubern, «El ciclo antisemita del cine español de posguerra», en Román Gubern (ed.), Cultura audiovisual. Escritos. 1981-2011 (Madrid, Cátedra, 2013), pp. 295-301.

[50] Fernando González García, «Técnica, ideología y mercados. El discurso oficialista en el cine español entre 1929 y 1945», en Alfonso del Amo et al., Apuntes sobre las relaciones entre el cine y la historia (el caso español) (Salamanca, Junta de Castilla y León, 2004 ), p. 102. 
De todas formas, la paradójica excepción española no deja de ser sorprendente si pensamos que, en estos años, la industria cinematográfica nacional acogió un gran número de artistas y técnicos judíos de Europa central que huían de las persecuciones nazis y cuya presencia, junto al tradicional y autóctono esperpento, puede explicar la orientación marcadamente expresionista del cine español y la integración de técnicas típicas del cine alemán de la época de Weimar, en contraste con la influencia determinante de la escuela de montaje soviética en el cine italiano durante el régimen de Mussolini.

No cabe duda de que el cine de estos años vehicula estereotipos de carácter racial más que religioso o cultural: se reconoce a primera vista al judío por sus rasgos físicos que se acompañan de graves taras en el carácter: engañador, codicioso y vengativo. Uno de los judíos más acometedores aparece en iA mí la legión! (Juan de Orduña, 1942) interpretado por Arturo Marín (1894-1954), que ya habíamos visto como uno de los correligionarios del protagonista en La dama del armiño ${ }^{51}$. Ya Fernando Sanz Ferreruela, siguiendo el juicio de Rafael de España, había destacado el virulento carácter antisemita de esta obra de Juan de Orduña que describe las desaventuras de dos legionarios, uno de los cuales es acusado de un crimen que no ha cometido. En sus palabras:

En esta cinta encontramos a un hombre alto y delgado, de rostro y nariz afilada, luciendo una fina barba puntiaguda, ataviado con túnica y gorro semita y caminando sigilosa y sospechosamente por entre las oscuras callejuelas del zoco marroquí. Dicha descripción corresponde al personaje de Isaac Levi, un usurero prestamista judío [que comete sin ser visto un asesinato] durante la celebración de un baile en el que los legionarios han bebido más de la cuenta ${ }^{52}$.

Sin embargo, contrariamente a la opinión de Sanz Ferreruela, este no es un caso excepcional ni único. Por ejemplo, Amaya (Luis Marquina, 1951), basada en la novela histórica Amaya o los vascos en el siglo VIII, del escritor tradicionalista católico y carlista Francisco Navarro Villoslada (1818-1895), recupera el mito de la conspiración judía en la invasión musulmana de España y en el consecuente fin del reinado de los visigodos. La comunidad hebrea de Pamplona, reunida en «sanedrín» secreto después de la batalla de Guadalete de 711 y la muerte del rey don Rodrigo, recibe la visita del médico Asbén (judío siempre personificado por Arturo Marín), de nariz aguileña y joroba bajo su vestido de capa negra y mangas largas a rayas que parecen filacterias, quien anuncia haber envenenado al príncipe visigodo Ranimiro para destruir a los vascones, pactar
[51] Marín protagonizó otras películas en las que aparece como encarnación de la fuerza corruptora del mal, generalmente extranjero o ajeno a los valores consensuales. Así, es un tal Paulovich en la comedia Un hombre de negocios (Luis Lucia, 1945), un usurero en $E l$ Marqués de Santillana (Edgar Neville, 1948), un gitano en La Lola se va a los puertos (Juan de Orduña, 1947) o el jefe de espionaje en Sin uniforme (Ladislao Vajda, 1948), en un Marruecos internacional y multicultural donde también hay un judío de nombre Levi (José Isbert).

[52] Fernando Sanz Ferreruela, Catolicismo y cine en España (1936-1945) (Zaragoza, Institución Fernando el Católico, 2013), p. 327. 
[53] Según la interpretación pormenorizada de esta cinta presentada en Luis Mariano González González, Fascismo, pp. 6o-68, los judíos son los principales responsables del cainismo y de las luchas fratricidas que alimentan la historia española en su versión franquista.

[54] El marcado carácter antisemita y racista de esta zarzuela es objeto de dura condena por parte de Antonio García Seror, Ensayos sobre el hombre: arqueología, antropología $y$ religión (Guadalajara, Aache, 2005), p. 115.

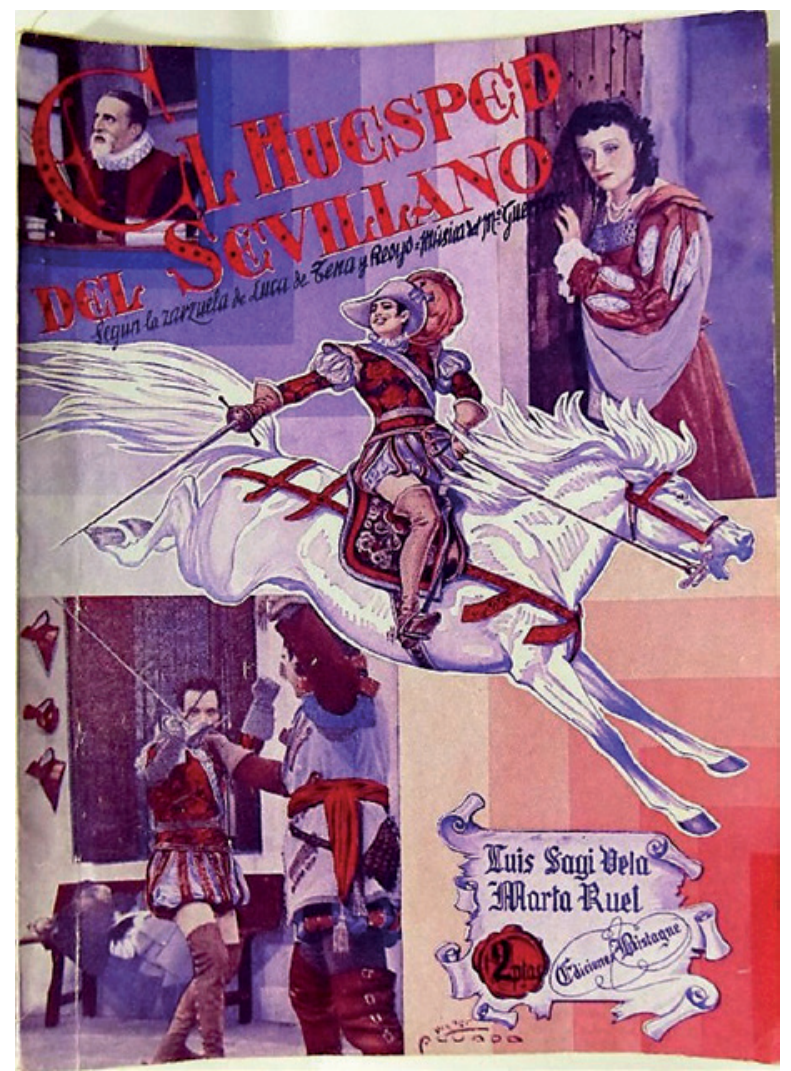

Cartel de El huésped del sevillano (Enrique del Campo, 1940). con los conquistadores árabes y elevar al trono al traidor Eudón, un godo aliado a la judería en su plan de dominar a España. Estos no son los únicos judíos que resaltan por su rapacidad e hipocresía en la trama. La cinta abunda en otros israelitas semejantes; algunos solo son mencionados: como el joyero David Sejar o como Basurde (difunto marido de la vasca pagana Amagoya, judío que se hizo pasar por vasco antes de ser póstumamente desenmascarado); y otros están presentes: como el concejero fraudulento de Eudón, Pacomio, jefe de la judería, pero al que se ve también a menudo disfrazado de fraile, o como la turba de la aljama de Pamplona, que organiza una matanza contra los vascos haciéndose pasar por godos para sembrar la discordia entre los cristianos y profanar a la iglesia local prefiriendo siempre a los enemigos de la cruz, exteriores, como los sarracenos, o interiores, como los vascos que aún permanecen apegados al paganismo ${ }^{53}$. A pesar de su fracaso de taquilla, la cinta recibió la calificación de «interés nacional» por parte de las autoridades del ministerio responsable de la industria cinematográfica. Quizás el voto de Israel ese mismo año contra la elevación de las sanciones internacionales a las que se hallaba sometida la España franquista esté relacionado con este postremo y descarado ejemplo de antisemitismo oficial. Indudablemente, a las autoridades no les debió de pasar desapercibida la posibilidad de identificar la situación desastrosa seguida a la derrota en el siglo VIII con la de la España contemporánea aislada en el contexto de la posguerra y el valor propagandístico del llamamiento de Amaya a la unidad de todos los elementos de la nación cristiana y bajo la dirección de un caudillo. El grito de Amagoya, ya reconciliada con Amaya, que reconoce al final de la película que «la aljama domina la ciudad y son los rabinos quienes dictan las ordenes», podría verse como una alusión al nuevo orden mundial bajo el eje de Estados Unidos, supuestamente sometido a los intereses de la plutocracia judeo-masónica internacional, de quien España sería la víctima inocente.

Lo mismo acontece con El huésped del sevillano (Enrique del Campo, 1940), basado en la zarzuela del mismo título de Juan Ignacio Luca de Tena y Enrique Reoyo del 1926, que tendrá un remake para la televisión española en 1970 dirigido por Juan de Orduña ${ }^{54}$. Aquí también, como en Isabel de Solís..., tenemos los personajes de un padre 
judío, maese Andrés Munestein (interpretado por Delfín Jerez), y de su hija Raquel (Marta Ruel). Maese Munestein es un judío converso y afamado espadero de Toledo que guarda a Raquel, hija nacida de su matrimonio con una cristiana vieja, como oro en paño. Sin embargo, esta se enamora de Juan Luis de Avendaño, caballero cabal y pintor de oficio, que la elegirá como modelo para su cuadro de la Inmaculada y se casará con ella después de varias aventuras propias del género de capa y espada. La película juega con un doble contraste: uno ideal, entre la pusilanimidad y la venialidad de quien hace las armas para venderlas, como el judío, y el coraje y la generosidad de quien sabe manejarlas; otro racial, entre la fisionomía claramente semítica del padre, servil, codicioso y embustero (como demuestra la presencia en la habitación del padre de una Menorah o candelabro de siete brazos, que parecería indicar su condición de judaizante a pesar de ser exteriormente cristiano), y la hija del rostro celestial que nos remite a una caracterización de los personajes donde la condición espiritual es consecuente a rasgos raciales que se pueden redimir solo con la mezcla de las sangres de razas distintas, en una España cervantina en la que ya no había más judíos que los descendientes de cristianos nuevos. Es probable que, para evitar cualquier mecanismo de eventual simpatía hacia el elemento hispánico propio de los judíos sefardíes ${ }^{55}$, al padre se le atribuya un patronímico que lo identifica como extranjero, a lo mejor askenazí, para distinguir su degeneración y mezquindad moral aún más marcadamente de la nobleza y de las virtudes ibéricas, a costa de cualquier verosimilitud histórica.

Parece, de todas maneras, como señala Álvarez Chillida, que, al pasar desapercibida la minoría judía para la mayoría de los españoles, las actitudes ante estos obedezcan sobre todo a las imágenes burdamente estereotípicas de los «judíos» en general en las que tienen peso la cultura tradicional castiza, ${ }^{6}$ pero también y sobre todo, el antisemitismo moderno europeo de matriz genético-biológica ${ }^{57}$.

No olvidemos que el cine en este periodo, que José Luis Castro de Paz ha apodado «los turbios años cuarenta» ${ }^{8}$, es un aparato ideológico del Estado. El tema judío está, por cierto, relacionado con factores internos y externos relativos a la política española bajo el franquismo, como señala Isabelle Rohr cuando escribe:

La relación hispano judía tiene tres dimensiones principales: la primera tiene un foco interno, ya que utiliza mitos que estaban arraigados en la ideología de la derecha radical española destacando, entre ellos, el mito de la reconquista y el mito de una conspiración judeo-masónica. La segunda tiene que ver con el imperialismo español en Marruecos y el papel que este asignó a los judíos. La tercera dimensión tiene un foco externo, ya que coloca la cuestión en el contexto más amplio de la política exterior de España, especialmente durante la Segunda Guerra Mundial 59 .
[55] Un filosefardismo muy vivo dentro del marco del nacionalismo español regeneracionista estudiado por Eva Touboul Tardieu, Séphardisme et Hispanité. L'Espagne à la recherche de son passé (1920-1936) (París, Presses de l'Université ParisSorbonne, 2009).

[56] Como las imágenes del judío vengativo y abyecto que aparecen de vez en cuando en las páginas de Mariano de Larra, de Gustavo Adolfo Bécquer, de Zorrilla o de Espronceda mencionadas por Norman Rehrmann, Das schwierige Erbe von Sefarad: Juden und Mauren in der spanischen Literatur. Von der Romantik bis zur Mitte des 20. Jahrhunderts (Frankfurt, Vervuert Verlagsgesellschaft, 2002). Rehrmann sostiene que, muy a menudo en el siglo xix, con la excepción de las novelas filosemitas de Antonio García Gutiérrez, la maurofilia, con su representación de árabes buenos y generosos, se acompaña del retrato de judíos malos y abyectos. Véase también Norbert Rehrmann, «El síndrome de cenicienta: moros y judíos en la literatura española del siglo xIx y xx", en Gonzalo Álvarez Chillida y Ricardo Izquierdo Benito (coords.), El antisemitismo en España (Cuenca, Universidad de Castilla-La Mancha, 2007), pp. 207-235; Norman Rehrmann, «Historia, literatura, identidad: El redescubrimiento de moros y sefardíes en la literatura española del siglo XIX $\mathrm{y}$ principios del $\mathrm{xx}$ " (Raíces, $\mathrm{n}^{\mathrm{o}}$ 36, 1998), pp. 35-43; Norman Rehrmann, El antisemitismo en España: la imagen del judío (1812-2012) (Madrid, Marcial Pons, 2002) y Alfonso Botti, «Questione sefardita e antisemitismo nell'Ottocento spagnolo» (Spagna contemporanea, 20, 2001), pp. 13-71.

[57] Gonzalo Álvarez Chillida, «Presencia e imagen judía en la España contemporánea. Herencia castiza y modernidad» en El otro en la España contemporánea, p. 146.

[58] José Luis Castro de Paz, Un cinema herido: los turbios años cuarenta en el cine español (Barcelona, Paidós, 2002).

[59] Isabelle Rohr, La derecha española y los judíos, 1898-1945. Antisemitismo y oportunismo (Valencia, PUV, 2010). 
[6o] Federico Ysart, España y los judíos en la Segunda Guerra Mundial (Barcelona, Dopesa, 1973) y Chaim Lipschitz, Franco, Spain, the Jews, and the Holocaust (New York, Ktav, 1984).

[61] Vease nota 29.

[62] Javier Domínguez Arribas, El enemigo judeo-masónico, p. 492.

[63] Tabea Linhard, Jewish Spain. Véase también Uriel Macías Kapón, «Los cronistas de la Guerra de África y el primer reencuentro con los sefardíes», en Uriel Macías Kapón, Moreno Koch e Izquierdo Benito (coords.), Los judíos en la España contemporánea, historia y visiones, 1898-1998, (Cuenca, Universidad Castilla-La Mancha, 2000), pp. 45-6o.
Es la última dimensión la que ha atraído más atención entre los estudiosos, con Federico Ysart y Chaim Lipschitz entre los que sostienen que Franco obró con todas sus fuerzas para salvar la mayor cantidad posible de judíos ${ }^{60}$, y con Haim Avni, Bernd Rother e Isabelle Rohr entre los que comparten una visión más crítica y matizada de las ambigüedades del franquismo frente a la destrucción del judaísmo europeo, corroborada como hemos podido demostrar hasta ahora por el número de películas de argumento antisemita producidas durante y poco después de la Segunda Guerra Mundial ${ }^{61}$. Los factores interiores han sido objeto del trabajo de Arribas para comprender las luchas en las cúpulas del poder franquista entre falangistas y nacional-católicos como «mecanismo para regular las tensiones y controlar la disidencia interior de cada facción» ${ }^{62}$. En este contexto se explicaría el recurso al tradicional antisemitismo ibérico como instrumento agregador entre las diferentes corrientes que componían la constelación ideológica de la derecha española. Sin embargo, falta todavía un análisis que tome en cuenta el tema judío en relación con la política colonial española, a pesar de algunas interesantes observaciones en la reciente obra de Tabea Linhard, que en el cine tiene solo los dos ejemplos que hemos aquí mencionado ${ }^{63}$.

De todas maneras, el cine de los años cuarenta parece haber respondido a solicitaciones internas más que a las relativas a los intereses de la política exterior del gobierno de Franco. Si la alianza con la Alemania nazi no parece haber tenido inmediatas consecuencias en la representación de los judíos -ninguna de las coproducciones hispano-alemanas de esos años, como las que vieron involucrado a Benito Perojo (1894-1974), parece haber sucumbido a la tentación de usar la figura del judío como cemento ideológico entre los dos gobiernos-, el judío, sin embargo, sí aparece bastante a menudo en las películas del régimen que intentan abastecer una visión de la historia nacional conforme con la ideología dominante para imponer una narrativa homogénea y determinista de la identidad española.

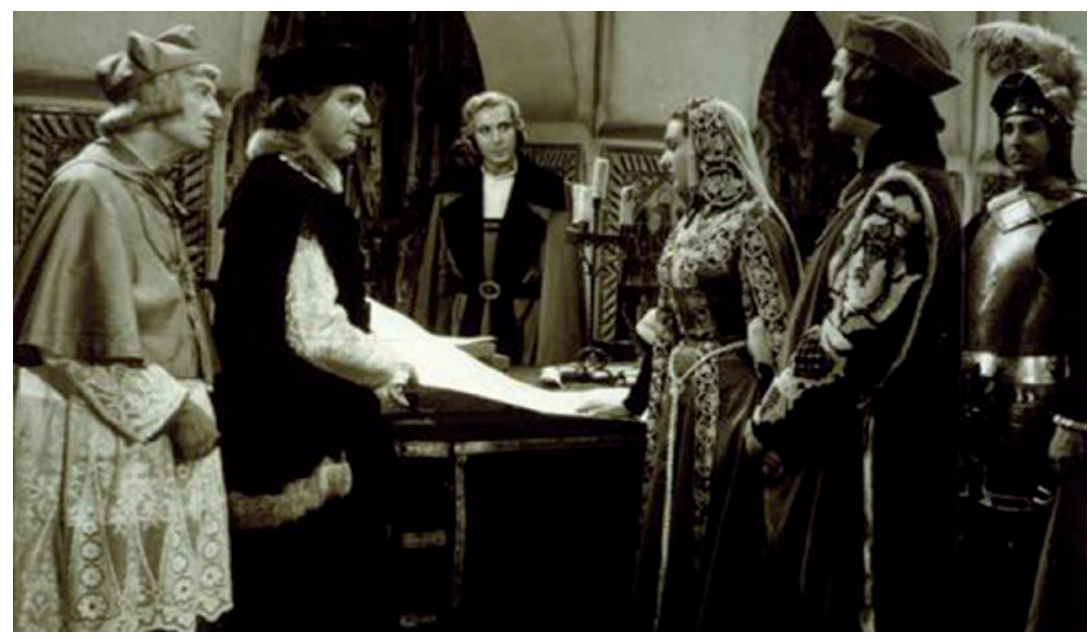

Fotograma de Alba de América (Juan de Orduña, 1951). 
Es importante subrayar que, con las excepciones de las dos películas de ambientación colonial donde aparecen judíos marroquíes contemporáneos, iA mí la legión! y Sin uniforme, todos los demás personajes de hebreos dependen en buena parte también de la importancia del genero histórico como instrumento de adoctrinamiento ideológico. Su presencia cubre el periodo que va desde el principio de la Reconquista con Don Pelayo, héroe de Amaya, hasta las victorias de los Reyes Católicos y la época de los descubrimientos, con $E l$ doncel de la reina (Eusebio Fernández Ardavín, 1946), donde el destino de Hernando, que sirve como doncel a la reina Isabel, se cruza fugazmente con el de una joven judía granadina antes de que, por azares de la vida, termine embarcándose en una carabela rumbo a las Indias; y sobre todo con Alba de América (Juan de Orduña, 1951), otra producción de Cifesa (y, como Amaya, película clasificada de «interés nacional»), donde aparece la figura del banquero Isaac (Manuel Luna) ${ }^{64}$, definido como «un negociante ruin» que intenta corromper a Cristóbal Colon y que, frente a su rechazo, hará lo posible para que fracase en sus intentos ${ }^{65}$.

En esta recuperación del medievo como edad pura y auténticamente cristiana, tan enfatizada en la estética fascista española, el judío representa la antítesis de los valores idealizados por el nacional catolicismo, con su cosmopolitismo desarraigado, su falta de nobleza y su apego al lucro, sin solidaridad ni siquiera con sus compañeros de fe.

Otro contexto histórico, como hemos visto, en el cual no faltan algunas figuraciones de judíos, pero esta vez a modo de sub specie de conversos judaizantes o sinceros cristianos, es el Siglo de Oro, con El huésped del sevillano y La dama del armiño. Aquí, al judío, identificado como potencial disidente que la máquina represiva del Estado representada por el Santo Oficio debe paternalistamente controlar, se le ofrece un horizonte de redención, a condición no solo de abandonar sus anteriores creencias, sino también de limpiar su mancha racial incorporándose por casamiento a la sociedad mayoritaria.

Un caso aparte, siendo una da las raras obras fantásticas del cine español de la época y también por la calidad estética del producto, que remite al cine alemán gracias al corte expresionista del decorado de Pierre Schild, es La torre de los siete jorobados (Edgar Neville, 1944), basada en la novela gótica de Emilio Carrere (18811947). Esta es la única obra cinematográfica que inserta a los

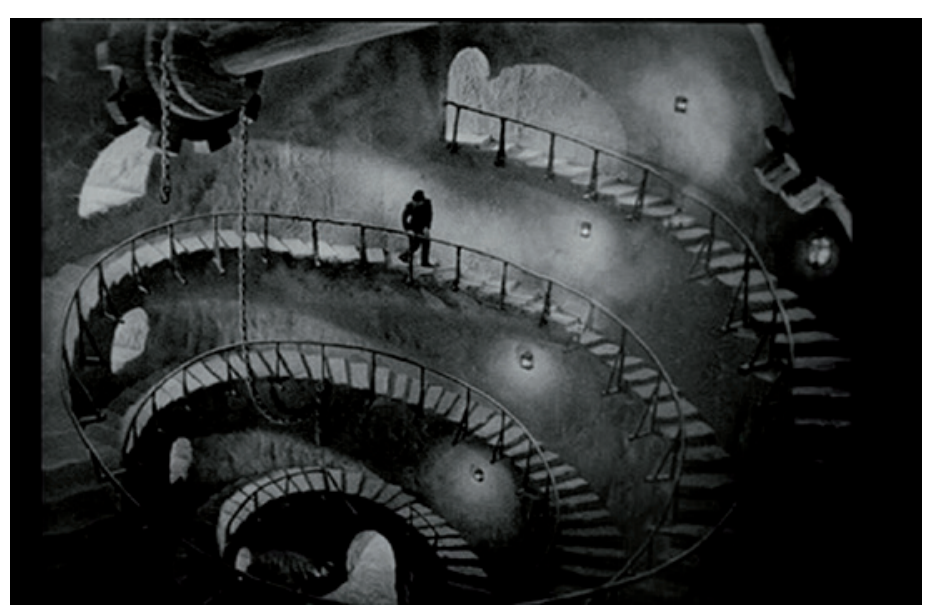

Fotograma de La torre de los siete jorobados (Edgar Neville, 1944). 
[66] Protagonista de la novela de George du Maurier, Trilby (Londres, 1895), y héroe de varias películas en la historia del cine internacional.

[67] José Luis Borau, «El cine religioso", Diccionario del cine español (Madrid, Alianza Editorial, 1998), p. . 740. Es la época en la que, según Alberto Elena, el cine colonial se desvía «hacia un cine religioso en el que la misión civilizadora se entiende casi exclusivamente como una obra misionera». "La llamada de África: una aproximación al cine colonial español» (Cuadernos de la Academia, $\mathrm{n}^{0} 1$, 1997), p. 251.

[68] Juan Antonio Martínez Breton, Influencia de la Iglesia católica en el cine español (1951-1962) (Madrid, Harofarma, 1987). judíos en una época muy cercana a la contemporánea, en el corazón de Madrid de finales del siglo decimonoveno donde el enigmático fantasma del doctor Robinson de Mantua, un arqueólogo dotado de todos los carices icónicos de un Caligari castellano, el personaje doble del film de Wiene (El gabinete del dortor Caligari [Das Kabinett des Dr. Caligari], 1920), revela al joven y un tanto atolondrado Basilio la existencia de una ciudad subterránea en la que habitan siniestros jorobados dedicados a actividades criminales, desde la falsificación de dinero hasta asesinatos. Tales individuos son judíos que han sobrevivido en este escondite a la Inquisición y que mantienen secuestrada e hipnotizada a Inés, la sobrina del difunto doctor. Su jefe, Don Sabatino (Guillermo Marín), digno de la mejor tradición antisemita que tiene su más ilustre antecedente cinematográfico y literario en el personaje de Svengali ${ }^{66}$, tiene poderes ocultos que utiliza contra sus víctimas. Armado de su amor por la sobrina del doctor de Mantua, Basilio logra al fin rescatar a la muchacha y destruir el tétrico lugar junto a sus habitantes. Semejante metáfora del judaísmo, como gangrena social en la España moderna y percibida como amenaza subterránea, no deja de ser escalofriante al pensar que la destrucción de las comunidades judías se estaba efectivamente cumpliendo en Europa por mano de regímenes ideológicamente afines al de Franco.

\section{El franquismo: segunda época (de 1952 a 1975)}

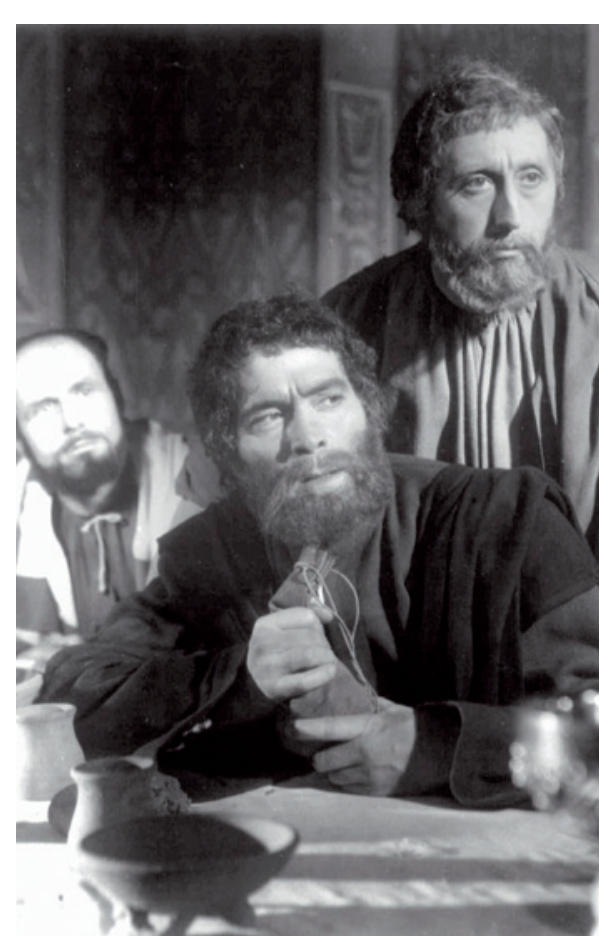

Fotograma de El Judas (Ignacio F. Iquino, 1952).
Sea lo que sea, no debe extrañarnos que las connotaciones del más zafio antisemitismo desaparezcan con los primeros signos de estancamiento del cine de cruzada, con el definitivo colapso del género histórico y con el consiguiente auge del cine religioso cuando, como escribe Borau con tino, «el uniforme castrense se sustituye por la sotana preconciliar» ${ }^{67}$. El cine clerical, ya en vísperas del Concilio Vaticano II, con el espíritu de conciliación ecuménica instaurada por la Iglesia de Juan xxiII y acelerada por su sucesor Pablo vi, evita cuidadosamente apelar al tradicional odio popular hacia los judíos. Esto ocurre en España sobre todo con el nombramiento en 1951 del ultra católico Gabriel Arias Salgado al frente del ministerio del que depende la cinematografía, sin olvidar el cambio inducido por la firma del concordato con el Vaticano en $1953^{68}$.

Sin duda, la victoria definitiva del nacional-catolicismo con el consecuente recorte de la influencia del falangismo, el paulatino abandono de las prácticas autárquicas y el ingreso de España en la ONU (1955), eventos premonitorios de la España aperturista y del desarrollismo económico, tienen una repercusión casi inmediata en la manera de representar al judío en el cine. 
Algunas películas de los años cincuenta comparten una atención a la temática judía ya prácticamente desprovista de saña antisemita y en un contexto de producción masiva de películas de género que, en la mayoría de los casos, compartían una finalidad claramente evasiva y de entretenimiento. Así, tenemos: El Judas (I. F. Iquino, 1952), que relata el drama de un personaje abyecto que, en la representación de la Pasión de Esparraguera, ambiciona obtener el papel de Jesús a cambio del de Judas que le es siempre atribuido; Bienvenido Mister Marshall (Luis G. Berlanga, 1952), donde el cura del pueblo que debería acoger a los americanos está obsesionado por el número de judíos que viven en Estados Unidos; y Un americano en Toledo (Carlos Arévalo, 1957) ${ }^{69}$, comedia de enredo desencadenada por la pretensión de un profesor de idiomas americano de instalarse en una casa en la antigua judería toledana, ahora habitada por una inquilina cristiana, que le vendió un judío de Salónica descendiente de sus antiguos propietarios. No hay que olvidar al personaje de Isaac Blum en las diferentes adaptaciones cinematográficas de la comedia teatral de Enrique Jardiel Poncela, Las cinco advertencias de Satanás, estrenada en 1935, de las que progresivamente desparece la fuerte caracterización antisemita del judío polaco excesivamente ahorrador y rastrero con barba y traje desgastado presente en el original. Queda solo el nombre insólito para reconocer la probable identidad religiosa del austero administrador de las fortunas del protagonista, hombre de mediana edad y de vida disipada (de la versión de Isidro Socías, de 1938, hasta la de José Luis Merino, de 1970).

Sin embargo, entre 1957 y el 1975, cuando el único «otro» en las pantallas españolas es el turista adinerado, preferiblemente de sexo femenino y de Europa septentrional ${ }^{70}$, la temática judía desaparece casi por completo de las pantallas españolas tanto por lo que concierne a los productos de importación, rígidamente sometidos a censura, como a las producciones locales, con algunas excepciones y siempre en un contexto bíblico ${ }^{71}$.

Nos encontramos en una época en la que el discurso oficial del régimen franquista deja de incluir a los judíos entre sus peores enemigos, desviando su atención sobre los masones y comunistas. En este sentido, el antisemitismo resulta mucho más coyuntural que el antimarxismo, que figura como uno de los componentes cardinales del discurso legitimador del régimen a lo largo de su existencia. Pese a ello, se censuraron las informaciones, especialmente las gráficas, sobre el genocidio judío y los campos de exterminio alemanes hasta tiempos muy cercanos a la Transición. No extraña, por lo tanto, que en un contexto como el español, donde películas como Roma, ciudad abierta (Roma cittá aperta, Roberto Rossellini, 1945) no fueron estrenadas hasta 1976 y donde en la versión castellana de $E l$ extraño (The Stranger, Orson Welles, 1946) se transformara el personaje del nazi en el de un soviético, fueran también censuradas algunas películas americanas que trataban de temas judíos como: El gran dictador (The Great Dictator, Charlie Chaplin, 1940), que no se vio en España hasta 1976, Ser o no ser (To be or not to be, Ernst Lubitsch, 1942) 72 $^{2}$ La barrera invisible (Gentleman's Agreement, Elia Kazan, 1947) ${ }^{73}$ y Oliver Twist (David Lean, 1948) ${ }^{74}$. También Los ángeles perdidos (The Search, Fred Zinnemann, 1948) fue censurada, lo que llegó a provocar
[69] Fernando Sanz Ferreruela, Catolicismo y cine en España p. 329.

[7o] Casimiro Toreiro, en Román Gubern et al., Historia del cine español (Madrid, Ed. Catedra, 1995), p. 295.

[71] El análisis de judíos que aparecen en las películas inspiradas en la Biblia plantean algunos problemas metodológicos que cabe tratar en otra ocasión.

[72] Alberto Gil, La censura cinematográfica en España (Barcelona, Ediciones B, 2009), p. 289.

[73] La censura de la película La barrera invisible, de Elia Kazan, la producción con mayores recaudaciones de 1947, es objeto de análisis en Eva Woods Peiró, White Gypsies, pp. 3-17.

[74] Emeterio Diez Puertas, Historia social del cine en España (Madrid, Fundamentos, 2003), p. 287. 
[75] Pablo León de Aguinaga, Sospechosos habituales. El cine norteamericano, Estados Unidos y la España franquista, 1939-196o (Madrid, CSIC, 2010), p. 263.

[76] Rafael Heredero García, La censura del guion en España (Valencia, Generalitat, 2000), p. 145.

[77] Íbid, p. 293.

[78] Íbid, p. 294.

[79] El ejemplo más discutido es el de la película sobre Auschwitz Noche y niebla (Nuit et brouillard, Alain Resnais, 1955) donde solo una vez se habla de víctimas judías. Véase en lo que concierne al cine americano Lester Friedman, Hollywood's Image of the Jew, (New York, Ungar, 1982), pp. 55-87, donde se trata de los Frightened fifties, y Claudine Drame, Des films pour le dire: reflets de la Shoah au cinéma Francais, 1945-1985 (Ginebra, Metropolis, 2007), que habla de una incapacidad y un desinterés en Francia por la representación del sufrimiento judío. No muy distinta es la situación en los mismos años en el cine israelí; véase Moshe Zimmermann, Al Tigu Li Ba-Shoah: Hashpaat Ha-Shoah Ba-Qolnoa U-baHevrah Be-Israel (Non toccatemi la Shoah: Influenza della Shoah sul cinema e la società in Israele) (Haifa, 2002). En lo que concierne a Italia, véanse mis artículos ya mencionados.

[80] 1960, el año del proceso a Eichmann en Jerusalén, es también el que conoce el mayor éxito internacional de superproducciones de Hollywood inspiradas en la tragedia del judaísmo europeo durante la Segunda Guerra Mundial, como

El diario de Ana Frank, Kapò (Gillo Pontecorvo, 1960), Éxodo (Exodus, Otto Preminger, 1960) o ¿Vencedores o vencidos? (Judgment at Nurenmberg, Stanley Kramer, 1961).

encendidas quejas del productor judío americano Arthur Loew ${ }^{75}$. En los cincuenta fue prohibida la importación de Decisión al amanecer (Decision before Dawn, Anatole Litvak, 1951) por la razón de ser una «película de guerra y espionaje que fomenta el odio y el rencor contra los alemanes vencidos» $y$, con un similar pretexto, por tener alusiones a «la venganza judía», fue vedada también Operación Calais (Soldatensender Calais, Paul May, 1960)76. Si Espía por mandato (The Counterfeit Traitor, George Seaton, 1962) fue retirada «por tratar de la cuestión racial en Alemania", de Fugitivos del terror rojo (Man on a Tightrope, Elia Kazan, 1953) se mandó suprimir «la frase alusiva a que el padre murió en una cámara de gas "77 y El diario de Ana Frank (The Diary of Anna Frank, George Stevens, 1959) fue autorizada, pero solo para mayores de 18 años por «la presentación de los judíos como excelentes en todos los aspectos» y por el «moroso y morboso desarrollo de la película, violenta filípica contra la conducta de los alemanes con los judíos, la hace indigerible para la infancia» ${ }^{78}$.

Esta es la segunda gran paradoja -o, si se quiere, un ulterior ejemplo del anacronismo franquista y de la hibernación intelectual en la que estuvo sumido el país- que resulta de nuestra reconstrucción histórica y que distingue a España de las cinematografías de otros países occidentales donde, después de una fase de latencia en los años cincuenta $^{79}$, se conoce en la década siguiente una explosión de películas de interés judío ${ }^{80}$. El dato es particularmente sorprendente en el marco del aumento de producciones y coproducciones internacionales realizadas en España en los años sesenta y setenta $^{81}$, con más de cien largometrajes por año en el periodo de lozanía del Nuevo Cine Español bajo la supervisión de José María García Escudero (19162002 $)^{82}$. A pesar de la influencia de nuevas tendencias culturales

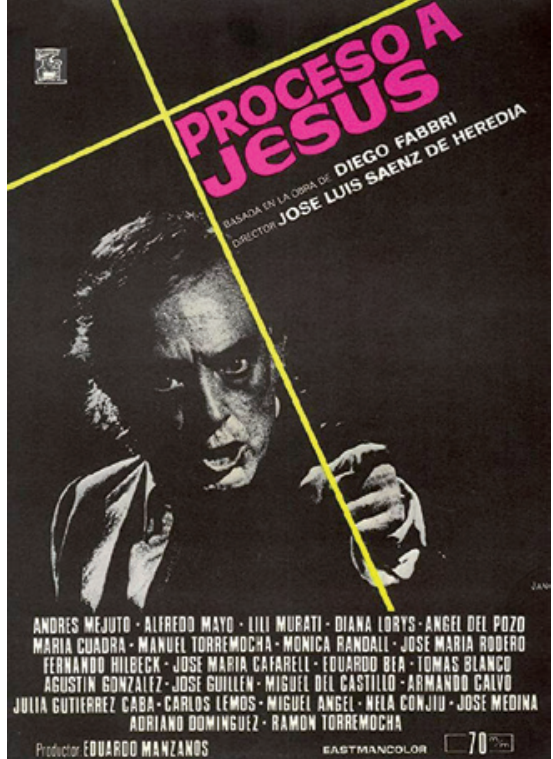

Cartel de Proceso a Jesús (José Luis Saenz de Heredia, 1973).

[81] Santos Zunzunegui, Los felices sesenta. Aventuras y desaventuras del cine español (1959-1971) (Barcelona, Paidós, 2005).

[82] Solo en el quinquenio de Escudero entre 1962 y 1967 se produjeron 770 films, una cantidad casi idéntica a las 779 películas producidas en España en el periodo del gobierno del Partido Popular entre 1996-2003. Datos en José María Caparros Lera, Historia del cine español (Madrid, T \& B Editores, 2007), pp. 298 y 307. 
provenientes del extranjero, en lo que concierne a los temas de interés judío, el cine nacional está lejos de hacerse eco de las disputas que apasionan a la intelectualidad europea alrededor de la dimensión judía del sufrimiento de las víctimas del nazismo durante la Segunda Guerra Mundial.

El interés político - muy a menudo a través de versiones sexualizadas de las relaciones de poder entre verdugos nazis y sus víctimas, bajo el influjo de las teorías de Foucault- se manifiesta en España con casi una década de retraso. Antes que el Holocausto judío es la Inquisición y, sobre todo, la expulsión de los judíos en 1492, que pasa a ser reinterpretada radicalmente y a veces redescubierta por completo. Es emblemática en este sentido la película Proceso a Jesús, realizada por José Luis Sáenz de Heredia en 1973, en las postrimerías del franquismo; mientras que en la pieza del italiano Diego Fabbri ${ }^{83}$ se refería al sufrimiento judío durante la Segunda Guerra Mundial, en la versión española se substituyen las travesías impuestas al pueblo de Israel por el Santo Oficio.

\section{La Transición}

Es solo con el fin del franquismo cuando el cine empieza a acoger la visión tricultural de la historia ibérica defendida por Américo Castro ${ }^{84}$. Sin embargo, cuando esto ocurre, el contexto ha cambiado substancialmente: estamos ya en una España largamente secularizada, reacia a la religión, enfrentada a reivindicaciones autonomistas. Por lo tanto, lo judío, en tanto que fenómeno religioso perteneciente a un lejano pasado, tampoco atrae demasiada atención en los primeros años de la Transición.

No se puede, sin embargo, estar de acuerdo con Rafael de España cuando afirma que: «el cine de la España libre y democrática ha mostrado por el judaísmo mucho menos interés que la España del franquismo» ${ }^{85}$. Todo lo contrario. En efecto, los dos tercios de las cuarenta y seis películas que hemos recogido han sido realizados en los últimos cuarenta años de democracia. El número es aún más considerable si se toman en consideración, además de los largometrajes, también los documentales, que conocen una verdadera explosión en los últimos quince años. Como revela Cristina Martínez-Carazo:

De la homogeneidad racial, lingüística, religiosa y cultural potenciada por el franquismo se ha pasado a la articulación de una España plural a cuyo sustrato, forzadamente uniforme, se han superpuesto las identidades periféricas y el mosaico de culturas inherentes a la inmigración ${ }^{86}$.

Además, en el contexto de las identidades fluidas de la posmodernidad, se ha manifestado también un fuerte deseo hacia la recuperación de identidades fuertes y arraigadas para contrastar el sentimiento de alienación cultural debido a la globalización, a la integración europea y al fin de los grandes combates ideológicos de la Guerra Fría. No obstante, a lo mejor justamente por eso, el cine cae muy a menudo en la simple nostalgia o en el afán de recuperar el pasado pretérito con recuperaciones lacrimosas, como por ejemplo en el filme
[83] Sobre el contexto italiano de esta obra, véase Elena Mazzini, «Il Processo a Gesù di Diego Fabbri e i commenti della stampa cattolica italiana. Fra deicidio e persecuzioni» (Storicamente, No 7, 2011).

[84] Por ejemplo, cuando en España en su historia (Buenos Aires, 1948) y, más tarde, en $L a$ realidad histórica de España (México, 1954) escribe que «la realidad histórica de Europa puede entenderse sin necesidad de situar a los judíos en un primer término; la de España no».

[85] Rafael de España, "Antisemitismo en el cine español» (Film-Historia, $\mathrm{n}^{\circ}$ 1, 2 1991), pp. 96.

[86] Cristina Martínez-Carazo, «Inmigración en el cine español: el Otro que es siempre el mismo», en Imágenes del otro. Identidad e inmigración en la literatura y el cine, Montserrat Iglesias Santos (ed.) (Madrid, Biblioteca nueva, 2010), p. 185. 
[87] Beatriz Leal Riesco, «La Melilla fronteriza e intercultural a través de los ojos de sus creadores: Driss Deiback y Moisés Salama», en Fernando Ramos (ed.) Arte y ciencia. Creación y responsabilidad, (Coímbra, Universidad de Granada y CIMA, 2010), pp. 93-116.

[88] La versión cinematográfica de Javier Aguirre de 1981, Vida/Perra, está ambientada en la provincia española y no contiene ninguna referencia al universo cosmopolita de la protagonista en Tánger. Sobre el film de Benlyazid véase Veronique Bonnet, «La vida perra de Juanita Narboni de Farida Benlyazid : une réécriture filmique postcoloniale ?» (Itinéraires, 2012-3), pp. 81-94; y también Thabea Linhardt, Jewish Spain, a Mediterranean Memory (Stanford, Stanford University Press, 2014), chapter 4.

[89] Este acta fue realizada en aplicación del decreto del 10 de diciembre de 2004 que instituía la obligación de conmemorar el día del Holocausto en enero en la fecha de la liberación del campo de exterminio de Auschwitz. Véase Danielle Rozenberg, La España contemporánea y la cuestión judía (Madrid, Marcial Pons, 2010), p. 287.

[9o] Benzion Netanyahu, Toward the Inquisition: Essays on Jewish and Converso History in Late Medieval Spain (Ithaca, Cornell University, 1997).

[91] Emmanuel Vincenot, «Alou, Said, Mihai et les autres : les immigres dans le cinéma espagnol des années quatre-vingt-dix», en Nancy Berthier (ed.), Penser le cinéma espagnol (1975-200o), (Lyon, GRIMH/GRIMIA 2002), pp. 87-95. Sobre el cine de esta época véase Francisco María Benavent, Cine español de los noventa (Bilbao, Ed. Mensajero, 2000). (La traducción es nuestra). documental El último sefardí (Miguel Ángel Nieto, 2003). Quizás tan solo los documentales Natural de Melilla (Driss Deiback, 2002) y Melillenses (Moisés Salama, 2004) ${ }^{87}$, así como la película de ficción La vida perra de Juanita Narboni (Laila Benlyazid, 2004) ${ }^{88}$-que cuenta el esplendor y la decadencia de Tánger como ciudad cosmopolita entre los años cuarenta y setenta del pasado siglo, a través del personaje de una solterona católica que se queda sola en la ciudad abandonada por su criada musulmana y por su amiga judía que emigró a Canadá-, todas producidas en España pero filmadas por directores melillenses o marroquíes, tienen la originalidad de no caer en la retórica de la convivencia multicultural.

En este periodo se pueden identificar por lo menos dos cesuras temporales. La primera se sitúa alrededor de las conmemoraciones de la expulsión de los judíos y del Quinto Centenario del descubrimiento de América en 1992. La segunda empieza en la fecha del 27 de enero de 2005 cuando, por primera vez en España, se tuvo en las Cortes una ceremonia en memoria de las víctimas del Holocausto ${ }^{89}$. En los primeros años de la Transición, el cine descubre su vocación transgresiva respecto a los valores tradicionales del régimen pasado (Iglesia, familia y ejército), y el judío aparece sobre todo como figura antitética a ellos, a pesar de que carezca de voz propia y de nombre. Ejemplares en este sentido son las cintas La portentosa vida del padre Vicente (Carles Mira, 1978), que pone en ridículo la figura del padre Vicente Ferrer, insistiendo en sus supersticiones, su beatería y su intolerancia, especialmente hacia los judíos, y Cristóbal Colon... de oficio descubridor (Mariano Ozores, 1982), comedia donde se muestra a un Torquemada tan encendido contra los judíos que empieza a gesticular y hablar delante de los Reyes Católicos como si fuera un pequeño Hitler ante litteram, visión correspondiente a la tesis del historiador israelí Benzion Netanyahu, que veía en las leyes de pureza de sangre los pródromos de lo que será la teoría racial del nazismo ${ }^{90}$.

Con todo, los años noventa «han sido para el cine español los de la apertura al exterior ${ }^{91}$. No solo se asoman algunas tímidas tentativas de interrogar la culpabilidad española en la expulsión de los judíos, como en La marrana (José Luis Cuerda, 1992), y estigmatizar la enseñanza al desprecio de los judíos en el sistema educativo del franquismo, como en El florido pensil (Juan José Porto, 2002), sino que también se empieza a tratar el exterminio de los judíos durante la Segunda Guerra Mundial. Con la excepción de un insulto de carácter antisemita y sexista en la comedia de género soft-porn Historia de «S» (Francisco Lara Polop, 1978), cuando el señor Alfredo, el protagonista, decide vestirse como Hitler, subir el volumen del transistor a las tantas de la madrugada, sacar a su mujer de la cama cogiéndole por los pelos y plantarle la bota en la cara mientras le grita «esclava judía», la primera película española que menciona al Holocausto judío, en un contexto muy problemático de venganza y sin alguna verosimilitud histórica, es La herencia del mal (Joaquín Gómez Sainz, 1987). En este film de terror de serie B, que casi no tuvo distribución, unos judíos quieren matar al padre de la misteriosa y riquísima dueña de un castillo, donde 
ha encontrado refugio el protagonista, Tony, por haber sido general en el ejército de Hitler. Del mismo género, aunque de mejor calidad que la precedente y con la misma percepción del judío como personaje vengativo, rapaz y dotado de poderes sobrenaturales, es Intacto (Juan Carlos Fresnadillo, 2001), que presenta a Max von Sydow en el papel de Sam, superviviente del Holocausto y, por lo tanto, dotado de un extraordinario don de la suerte que utiliza para acumular una fenomenal fortuna en un misterioso y casi inaccesible casino de su propiedad. Un singular pero fracasado intento de enfocar las relaciones entre el régimen franquista y el hitlerismo aparece en La niña de tus ojos (Fernando Trueba, 1998). Inspirada en hechos reales, el rodaje en Alemania de Carmen, la de Triana (Florián Rey, 1937) por Imperio Argentina ${ }^{92}$, el film relata cómo un grupo de cineastas españoles, con la guerra civil casi terminada, se traslada a Berlín para realizar una película invitados por Joseph Göbbels. Aquí tienen la oportunidad de descubrir la política persecutoria y antisemita del régimen nazi asistiendo atónitos al pogrom de la Kristallnacht. Todos los personajes de españoles, hasta los más fanáticos franquistas que componen la troupe, se distinguen de los nazis por su humanidad y compasión hacia los judíos sacados de campos de concentración para figurar como extras en el papel de gitanos, con los cuales comparten generosamente sus paellas, gran unificadora entre los pueblos, a pesar de las miradas amenazadoras de los guardas alemanes. Para los españoles, sea cual sea su bando, nada distingue a los judíos de ellos mismos porque, como dice uno de los personajes, «tienen pinta de andaluces» y porque son «tan cristianos como nosotros».

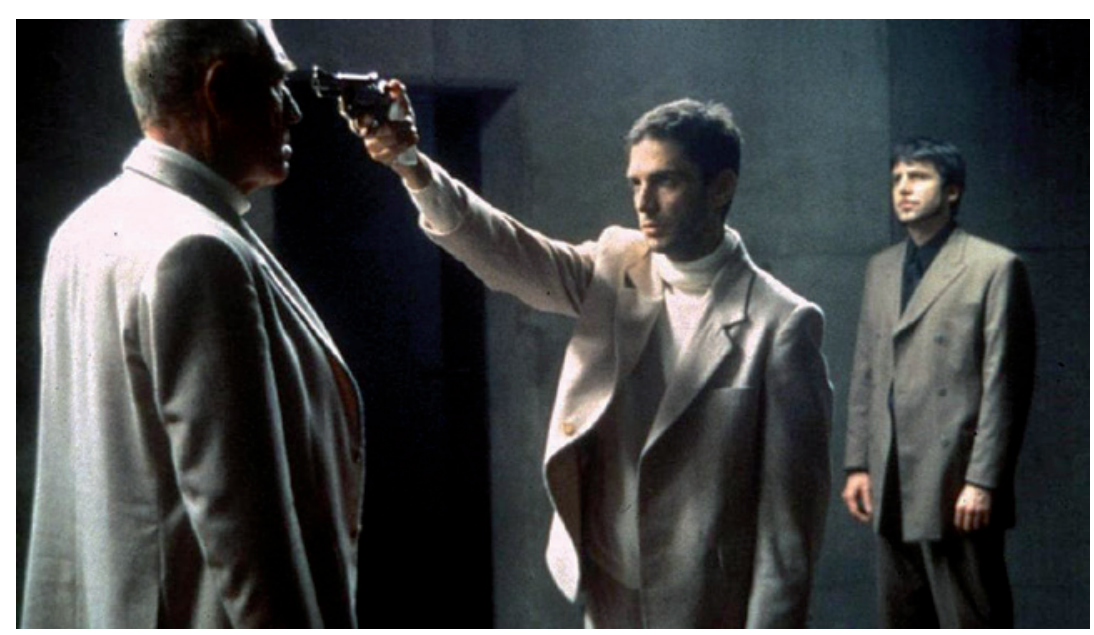

Fotograma de Intacto (Juan Carlos Fresnadillo, 2001).

En realidad, solo en la última década se puede constatar una presencia judía en constante aumento, en contextos independientes de la simple reflexión autorreferencial sobre la historia española. Varias, por ejemplo, son las películas que tratan del Holocausto ${ }^{93}$, aunque a menudo de manera pro-
[92] Manuel Nicolás Meseguer, La intervención velada. El apoyo cinematográfico alemán al bando franquista (1936-1939) (Murcia, Universidad de Murcia, 2004), pp. 11-116, 128-144.

[93] El silencio antes de Bach (Pere Portabella, 2007) y, entre los documentales, destacamos El diari d'Anna Frank (Tamyin Townsend, 1996) para Televisió de Catalunya; MauthausenViaje al infierno (Cesc Tomas, Rafael Robledo y Joan Sella, 2000); Ravensbrück -l'enfer de les dones (Joan Salvat, 2005) para la televisión catalana; Hitler-El lobo (José Delgado, 2006); El violinista de Auschwitz (Carlos Hernando, 2012), sobre un judío sefardí que logró salvar su vida gracias a que sabía tocar el violín. 
[94] Este tema ha sido objeto de varios documentales: Visados para la libertad (Ricardo Basterra y Arancha Gorostola, 2007), que trata también de la labor humanitaria que realizaron otros representantes de las delegaciones españolas en países de la Europa ocupada; Boira negra (Felip Solé, 2008), de Televisió de Catalunya; Ángel Sanz Briz, el Schindler español (Gonzo, 2008), para Antena 3. El número de los justos (Ignacio Sánchez, 2009), para TVE; La encrucïada de Ángel Sanz Briz (José Alejandro González, 2015).

[95] Tabea Alexa Linhard, «'Our Clown:' European Memory and Sentimental Nationality in Charlie Rivel's Unexpected Itinerary» (Bulletin of Spanish Studies, nº 94, 2017), pp. 91-110.

[96] Como, por ejemplo, en la película de Fernando Trueba $L a$ reina de España, secuela de $L a$ niña de tus ojos, donde se establece una natural complicidad entre una víctima judía del macartismo, los presos políticos de Franco condenados a trabajos forzados en el Valle de los Caídos y el director de cine Blas Fontiveros (Antonio Resines), superviviente de Mauthausen y al que los otros judíos americanos afincados en Madrid consideran, por eso mismo, como uno de los suyos; o el docudrama El camp de Argelers (Felip Solé, 2009), en el que aparecen imágenes reconstruidas e imaginarias de tumbas de internados judíos donde se ha dibujado sobre la cruz una pequeña estrella de David.

[97] Por ejemplo, Anas, una película india (Enric Miró, 2009), Un viaje al Mar Muerto (Chino Moya, 2010) o Nacido en Gaza (Hernán Zin, 2014).

[98] Por ejemplo, en el documental La dama dels escacs. Nascuda a Valencia, reina a tot el mon (Agustí Mezquida, 2012), que trata de Francesch Vicent, judeo-converso autor del primer tratado de ajedrez moderno, o el mediometraje Cábala caníbal (Daniel Villamediana, 2014). blemática y animada de buenos sentimientos autoconsolatorios, para demostrar el heroísmo de algunos españoles en el rescate de los judíos durante la guerra - como en la reciente El ángel de Budapest (Diego Carcedo, 2010)94 o El pallasso i el Führer (Eduard Cortés, 2007) ${ }^{95}-$ o para defender la idea de una solidaridad de destino entre los antifranquistas del exilio y los judíos acosados por la solución final ${ }^{96}$. El tema del conflicto en Oriente Medio está siempre más presente, sobre todo en el cine documental ${ }^{97}$, pero el único largometraje de ficción que aborda el problema de la convivencia entre judíos y palestinos es Seres queridos.

En general, se puede decir que el judío, después de haber tenido un papel instrumental en la Transición para estructurar una visión multiculturalista de España teñida de anticatolicismo, ahora, en la última década, aparece como piedra de toque para abordar los problemas de la inmigración y de los conflictos étnicos de la era postideológica. Por eso, su imagen pasa de ser caricaturesca y grotesca, como en la mayoría de las películas de los años ochenta, a trágica y más inclinada a captar la interioridad de los personajes judíos.

En un país con una de las comunidades judías más pequeñas de Europa, sigue siendo escasa la atención de la que han sido objeto los judíos actualmente residentes en la península, en particular los de origen sefardí. La suya es muy a menudo la imagen de una alteridad interna-incluida (como pueden ser las distintas declinaciones regionales de la diversidad hispánica) ${ }^{98}$ y no exenta de excluidos (como es en general la de los inmigrantes africanos). Un hilo conductor o una imagen recurrente es la de las llaves que encarnan la paradoja de pertenencia y exotismo de los judíos en el cuerpo nacional hispánico que, desde la época de Franco, llega hasta películas más recientes (del Americano en Toledo a El último sefardí).

Son recurrentes las figuras que aluden a un arraigo fuerte mientras, al mismo tiempo, aparecen marginales y dislocadas. Es ejemplar el caso del personaje de Salomón Toledo (Francisco Merino) en Maravillas (Manuel Gutiérrez Aragón, 1981), uno de los tres padrinos judíos sefarditas de la quinceañera protagonista Maravillas, prestidigitador de profesión, totalmente integrado en la familia disfuncional de la niña, pero muy excéntrico y cuyo cariño hacia la joven no le impide someterla a una arriesgadísima prueba de equilibrismo en el balcón de su casa para quitarle de una vez por todas el miedo a la vida. Es muy reveladora la manera de filmar la escena del matrimonio judío con la que se abre Caso cerrado (Juan Caño, 1985), que describe los problemas de conciencia de César, directivo judío en una entidad bancaria, que se niega a hacer el servicio militar y que, tras hallar irregularidades en las cuentas del banco en el que trabaja, empieza una lucha ímproba contra el sistema. A pesar de que el hecho de profesar la religión judía no tenga ninguna importancia en el desarrollo de la trama, más que por sus relaciones con el mundo de las altas finanzas, según un estereotipo muy común en la cultura popular, la cámara se detiene con una minuciosidad casi antropológica en todos los detalles más exóticos de la boda hebrea, resaltando el contraste entre la diversidad de los judíos en su intimidad y su total integración pública. 
Sin embargo, contrariamente a muchas representaciones de la alteridad, la judía no parece estar insertada en un contexto de atracción erótica ni tampoco de amenaza, como pudo serlo en el cine de Franco. Al judío se le asocia casi automáticamente el papel de la víctima inocente, como en Alatriste (Agustín Díaz Yanes, 2006), cuya acción acontece durante la guerra de los ocho años, en donde un personaje de converso portugués se suicida para no caer en manos de la Inquisición, y donde aparece Quevedo, de quien se condena el virulento

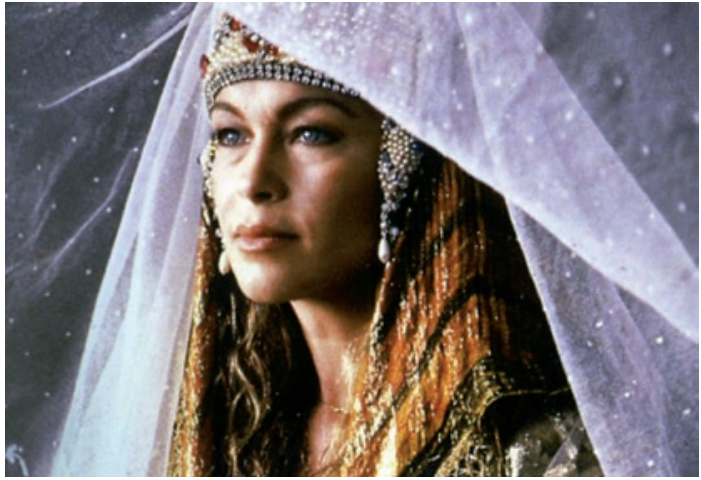

Marisol en Caso cerrado (Juan Caño Arecha, 1985). antijudaísmo. Además, los judíos no aparecen casi nunca asociados a los árabes en películas de ambientación orientalista, como si cada uno denotara distintas asociaciones culturales e históricas ${ }^{99}$. El judío, en general, no sirve para expresar el miedo por el reparto de riquezas, por la diferencia y el temor a la invasión. Con lo judío no hay, por lo tanto, identificación entre marginalidad y pobreza y no aparece entre los colectivos más visibles y menos susceptibles de integración de la actual sociedad multiétnica.

El judío está casi siempre representado como adinerado u ocupado en profesiones financieras e intelectuales, lo que lo exime de ser percibido como objeto de la xenofobia de la que son víctimas los trabajadores extranjeros y los inmigrantes ilegales ${ }^{100}$.

No estoy sin embargo enteramente de acuerdo con Tzvi Tal cuando afirma que «los judíos en el cine representan a la cultura española hegemónica a la que se han incorporado» ${ }^{101}$; de lo contrario, no se explica la acentuación folclórica de su diversidad en tantos films, de Maravillas a Caso cerrado y hasta Seres queridos. Mucho más a menudo, las comedias utilizan la coartada del judío de corte sainetesco en el desarrollo de su trama mientras que, en las películas de argumento serio, en constante aumento desde la ley de memoria del 2004, se hace patente un proceso de fetichizacion barroca de la muerte sacrificial y redentora de los personajes judíos, como en Intacto. En el cine español permanecen largamente -con recelos inconscientes- la interpretación cristológica del sufrimiento y del exilio judío (los tres «tíos» de Maravillas que recuerdan a los Reyes Magos) y la del complot típica de una sociedad percibida como estrictamente endogámica (solo en $\mathrm{Mi}$ querido Klikowsky y en Seres queridos hay una pareja mixta en un contexto muy conflictual ${ }^{102}$ ), encerrada en sí misma como la judía (siempre Maravillas, que anticipa una imagen del judío presente en Fanny y Alexander de Bergman [1982], pero también el personaje cómico de Chepa en Acción Mutante [Álex de la Iglesia, 1993], un enano jorobado, judío y masón, comunista y presuntamente homosexual, administrador y contable de la banda que da el nombre a la cinta).
[99] Aparte de la referencia a la convivencia de las tres religiones monoteístas en la España árabe del siglo viII, tela de fondo de la película Al Ándalus, el camino del sol (Jaime Oriol y Antonio Tarruella, 1989), los judíos en general aparecen en contextos históricos diferentes de la civilización musulmana en la península, como en Buñuel y la mesa del rey Salomón (Carlos Saura, 2001), Yo, Don Giovanni (Carlos Saura, 2009), que menciona el origen judío de Lorenzo Da Ponte, Agora (Alejandro Amenábar, 2009), con los judíos de la cosmopolita Alejandría en 391 a. C. o El discípulo (Emilio Ruiz Barrachina, 2010), sobre la vida de Jesús de Nazareth.

[10o] Hay que destacar la excepción de los documentales cortos de Estaban Ibarra sobre las varias expresiones del racismo en la sociedad española, por ejemplo, Informe Raxen, de 2010, Racismo y odio en internet, de 2011, o Las mentiras de la xenofobia, de 2011. El único documental que trata del tema del prejuicio antijudaico es a mi conocimiento ¿El estigma? (Martí Sans, 2014).

[101] Tzvi Tal, «Seres queridos y objetos étnicos: judíos y palestinos en la comedia cinematográfica española», p. 222.

[102] A eso se debe probablemente, como señala Tal, que muchas películas prefieran la «solución romántica y familiar que se sobrepone a las diferencias entre las identidades, a las concepciones ideológicas y a las posturas políticas». Tzvi Tal, «Seres queridos y objetos étnicos: judíos y palestinos en la comedia cinematográfica española», p. 215. 
[103] Martínez-Carazo, «Inmigración en el cine español», p. 188.

[104] Quizás el único caso de personaje cuya pertenencia al judaísmo no influye de alguna manera sobre su caracterización y aparece como totalmente anodino es Costa Brava (Marta Balletbo-Coll, 1995), que narra la relación sentimental entre Anna, una guía turística catalana, y Montserrat, una judía americana (ia pesar del nombre bien catalán y católico!), docente en la Universidad de Barcelona e insatisfecha con su trabajo.

[105] Zygmunt Bauman, «Allo-Semitism: Premodern, Modern, Postmodern», en Bryan Cheyette, Laura Marcus (eds.), Modernity, Culture, and «the Jew», (Palo Alto, Stanford University Press, 1998), pp. 143-156.

Como escribe Martínez-Carazo, «una deficiencia clave del cine español centrado en la inmigración es la inexistencia de textos fílmicos creados desde el punto de vista del inmigrante» ${ }^{103}$. Todavía hay que esperar filmes no ya sobre los otros étnicos, sino producidos por los mismos

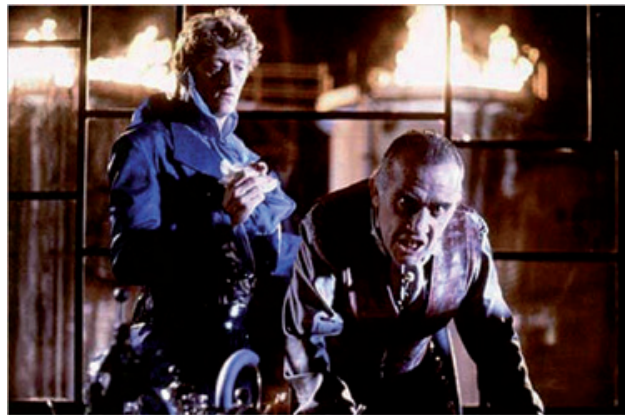

Fotograma de Acción mutante (Álex de la Iglesia, 1993). miembros de esta comunidad, y esto vale por los judíos también.

De todas formas y a pesar de que la alteridad judía no se encuentre entre las cuestiones identitarias que más inquietan a la España actual, un hecho resalta con bastante claridad en el conjunto del corpus examinado: la figura del judío en sus distintas reencarnaciones cinematográficas es siempre complementaria a un discurso con finalidades ideológicas. Su presencia en una película no es, por lo tanto, casi nunca accidental, fútil o anodina ${ }^{104}$. En el caso del cine español, estamos frente a lo que Zygmunt Bauman ha llamado «allosemitismo», o sea, la concepción que impregna buena parte de la cultura europea según la cual lo judío, para bien o para mal, representa una figura de alteridad que se resiste a una visión pacificada de valores y de identidades compartidas ${ }^{105}$. Eso no significa que todas las representaciones de los judíos padezcan de distorsiones antisemitas o sean necesariamente desdibujadas, sino que todo lo que concierne al judaísmo es el objeto de lo que Spivak denomina «imperialismo benevolente» dotando de voz al sujeto integrado al grupo hegemónico (por su idioma o por su historia compartida), pero afianzando la exclusión del otro marginal por su fe, por su origen. La palabra judío en el imaginario cinematográfico español permanece envuelta por una imperscrutable diversidad que puede ser resuelta solo a través de su incorporación en una red de significados que desvelan más la ideología dominante en España que la de la minoría judía para encararse a su sesgada y a veces incómoda presencia.

\section{BIBLIOGRAFÍA}

Alegre Calero, Sergio, «Las imágenes de la división azul; los vaivenes de la política exterior e interior de Franco a través del cine», en Aitor Yraola (co.), Historia contemporánea de España y cine (Madrid, Ediciones de la Universidad Autónoma, 1997), pp. 69-84.

Álvarez Chillida, Gonzalo, «Presencia e imagen judía en la España contemporánea. Herencia castiza y modernidad», en Silvina Shammah Gesser y Raanan Rein (coords.), El otro en la España contemporánea/ Prácticas, discursos, representaciones (Sevilla, Anfora, 2011), pp. 123-160. 
Avnı, Haim, «España y Portugal, su actitud respecto de los refugiados judíos durante la era nazi», en Ignacio Klich y Mario Rapoport (coords.), Discriminación y racismo en América Latina (Buenos Aires, Nuevohacer, 1997), pp. 255-271.

-, España, Franco y los judíos (Madrid, Altalena, 1982).

Bauman, Zygmunt, "Allo-Semitism: Premodern, Modern, Postmodern», en Bryan Cheyette, Laura Marcus (eds.), Modernity, Culture, and «the Jew» (Palo Alto, Stanford University Press, 1998).

Benavent, Francisco María, Cine español de los noventa (Bilbao, Ed. Mensajero, 200o). Bentley, Bernard P. E., A Companion to Spanish Cinema (Woodbridge, Tamesis, 2008). Bonnet, Veronique, «La vida perra de Juanita Narboni de Farida Benlyazid : une réécriture filmique postcoloniale?» (Itinéraires, 2012-3), pp. 81-94.

Borau, José Luis (dir.), Diccionario del cine español (Madrid, Alianza Editorial, 1998).

Bотті, Alfonso, «Questione sefardita e antisemitismo nell'Ottocento spagnolo» (Spagna contemporanea, 20, 2001), pp. 13-71.

Bros Duran, Montserrat, La imagen del mundo árabe en el cine español (1939-1975) (Barcelona, Universitat de Barcelona, 1992).

Calvet, Josep, Les muntanyes de la llibertat. El pas d'evadits pels Pirineus durant la Segona Guerra Mundial 1939-1944 (Barcelona, La Magrana, 2008)

CAmporesi, Valeria, «Para una historia de lo no nacional en el cine español. Ladislao Vajda y el caso de los huidos de las persecuciones antisemitas en España», en Nancy Berthier \& J.C. Seguin (eds.), Cine, nación y nacionalidades (Madrid, Casa de Velázquez, 2007), pp. 61-74.

Caparros Lera, José María, Historia del cine español (Madrid, T \& B Editores, 2007).

CASTRO de PAZ, José Luis, Un cinema herido: los turbios años cuarenta en el cine español (Barcelona, Paidós, 2002).

CRusells, Magí, Las brigadas internacionales en la pantalla (Cuenca, Universidad Castilla-La Mancha, 2001).

Diez Puertas, Emeterio, Historia social del cine en España (Madrid, Fundamentos, 2003).

Domínguez ArRibas, Javier, El enemigo judeo-masónico en la propaganda franquista (1936-1945) (Madrid, Marcial Pons, 2010).

DonNer, Batia y BonfiL, Rachel (eds.), From Here to Madrid. Volunteers from Palestine in the International Brigades in Spain 1936-1938 (Tel Aviv, Eretz Israel Museum, 2012)

Drame, Claudine, Des films pour le dire: reflets de la Shoah au cinéma français, 19451985 (Genève, Metropolis, 2007).

Ehrlich, Linda C., "A Change of Scene, a Change of Fortune: Cinematic Visions of the Sephardic Jew» (Shofar: An Interdisciplinary Journal of Jewish Studies, ${ }^{0}$ 15, 2, Winter 1997), pp. 1-20.

Elena, Alberto, «La Llamada de África: una aproximación al cine colonial español» (Cuadernos de la Academia, $\mathrm{n}^{0}$ 1, 1997), pp. 249-259.

-, La llamada de África, estudios sobre el cine colonial español (Barcelona, Bellatierra, 2010).

Ellwood, Sheelagh, «The Moving Image of the Franco Regime: Noticiarios y Documentales (1939-1975)», en Helen Graham y Jo Labanyi (eds.), Spanish Cultural Studies, (Oxford, Oxford University Press, 1995), pp. 201-203.

EsPaÑA, Rafael de, «Antisemitismo en el cine español» (Film-Historia, $\mathrm{n}^{0}{ }^{1,} 2$ 1991), pp. 89-102. 
Figares Romero de la CRUZ, María Dolores, La colonización del imaginario: imágenes de África (Granada, UGR, 2003).

Friedman, Lester, Hollywood's Image of the Jew (New York, Ungar, 1982).

Friedman, Michal, «Reconquering 'Sepharad': Hispanism and Proto-Fascism in Giménez Caballero's Sephardist Crusade», en Daniela Flesler, Tabea Linhard, Adrián Pérez Melgosa (eds.), Revisiting Jewish Spain in the Modern Era (London, Routledge, 2013), pp. 35-60.

García DE DueÑas, Jesús, «Samuel Bronston, ascenso y caída de un imperio», en Laura Gómez Vaquero y Daniel Sánchez Salas (eds), El espíritu del caos: representación y recepción de las imágenes durante el franquismo, (Madrid, Ocho y medio, 2009), pp. 435-473.

-, El imperio Bronston (Madrid, El Imán, 200o).

GARCÍA SEROR, Antonio, Ensayos sobre el hombre: arqueología, antropología y religión (Guadalajara, Aache, 2005).

Gil Gascón, Fátima, Españolas en un país de ficción. La mujer en el cine franquista (1939-1963) (Sevilla, Comunicación Social Ediciones, 2011).

GIL, Alberto, La censura cinematográfica en España (Barcelona, Ediciones B, 2009).

Gómez MESA, Luis, La literatura española en el cine nacional, 1907-1977 (Madrid, Filmoteca Nacional de España, 1978).

GonZÁlez García, Fernando, «Exiliados judíos del Tercer Reich en el cine español: 19331936» (Secuencias, $\mathrm{n}^{0} 37,2013$ ).

-, «Técnica, ideología y mercados. El discurso oficialista en el cine español entre 1929 y 1945», en Alfonso del Amo et al., Apuntes sobre las relaciones entre el cine y la historia (el caso español) (Salamanca, Junta de Castilla y León, 2004), pp. 97-110.

-, CAMPoresi, Valeria, «Un progreso en el arte nacional. Ibérica films en España, 19341936» (BSAA arte, $\mathrm{n}^{0}$ 77, 2011), pp. 265-286.

GonZÁlez GonZÁlez, Luis Mariano, Fascismo kitsch y cine histórico español (1939-1953) (Cuenca, Ediciones de la universidad Castilla-La Mancha, 2009).

GrafF Zivin, Erin, «Aporias of Marranismo: Sabina Berman's En el nombre de Dios and Jom Tob Azulay's O Judeu» (The New Centennial Review, $\mathrm{n}^{\circ}$ 12, 2012), pp. 187-216.

Gubern, Román, «Benito Perojo's La Verbena de la Paloma», en Jenaro Talens, Santos Zunzunegui (eds.), Modes of Representations in Spanish Cinema (Minneapolis, University of Minnesota Press, 1998), pp. 47-57.

-, «El ciclo antisemita del cine español de posguerra», en Román Gubern (ed.), Cultura audiovisual. Escritos. 1981-2011 (Madrid, Cátedra, 2013), pp. 295-301.

Gubern, Román et al., Historia del cine español (Madrid, Ed. Catedra, 1995).

Heredero García, Rafael, La censura del guion en España (Valencia, Generalitat, 200o).

Iglesias SANTos, Montserrat, «Representar al otro», Imágenes del otro. Identidad e inmigración en la literatura y el cine (Madrid, 2010).

JUARISTI, Jon, «Las bases míticas comunes de las identidades españolas modernas», en Silvina Shammah Gesser y Raanan Rein (coords.), El otro en la España contemporánea/Prácticas, discursos, representaciones (Sevilla, Ánfora, 2011), pp. 375-403.

KLich, Ignacio y Rapoport, Mario (coords.), Discriminación y racismo en América Latina (Buenos Aires, Nuevohacer, 1997).

LASTRA, James, «Why Is This Absurd Picture Here?», en Ivone Margulies (ed.), Rites of Realism: Essays on Corporeal Cinema (Durham, Duke University Press, 2002), pp. 200-205. 
Leal Riesco, Beatriz, «La Melilla fronteriza e intercultural a través de los ojos de sus creadores: Driss Deiback y Moisés Salama», en Fernando Ramos (ed.), Arte y ciencia. Creación y responsabilidad (Coímbra, Universidad de Granada y CIMA, 2010), pp. 93-116.

LeÓn de Aguinaga, Pablo, Sospechosos habituales. El cine norteamericano, Estados Unidos y la España franquista, 1939-1960 (Madrid, CSIC, 2010).

Linhard, Tabea Alexa, «'Our Clown:' European Memory and Sentimental Nationality in Charlie Rivel's Unexpected Itinerary» (Bulletin of Spanish Studies, $n^{\circ} 94,2017$ ), pp. 91-110.

-, Jewish Spain, a Mediterranean Memory (Stanford, Stanford University Press, 2014). Lipschitz, Chaim, Franco, Spain, the Jews, and the Holocaust (New York, Ktav, 1984).

LLINÁs, Francisco (coord.), Directores de fotografía del cine español (Madrid, Filmoteca española, 1989).

Lustiger, Arno, iShalom libertad! Judíos en la Guerra Civil Española (Barcelona, Flor al viento, 2001).

MACíAS KAPÓN, Uriel, «Los cronistas de la Guerra de África y el primer reencuentro con los sefardíes», en Uriel Macías Kapón, Moreno Koch e Izquierdo Benito (coords.), Los judíos en la España contemporánea, historia y visiones, 1898-1998 (Cuenca, Universidad Castilla-La Mancha, 2000), pp. 45-60.

Marquina, Antonio, «La política del régimen de Franco hacia los sefarditas nacionalizados», en Eloy Martín Corrales, La imagen del magrebí en España. Una perspectiva histórica (siglos XVI-XX) (Barcelona, Bellaterra, 2002).

- y Ospina, Gloria Inés, España y los judíos en el siglo XX (Madrid, Espasa Calpe, 1987).

Martínez Breton, Juan Antonio, Influencia de la Iglesia católica en el cine español (1951-1962) (Madrid, Harofarma, 1987).

Martínez-Carazo, Cristina, «Inmigración en el cine español: el Otro que es siempre el mismo», en Montserrat Iglesias Santos (ed.), Imágenes del otro. Identidad e inmigración en la literatura y el cine, (Madrid, Biblioteca nueva, 2010), pp. 185-198.

MazzinI, Elena, «Il Processo a Gesù di Diego Fabbri e i commenti della stampa cattolica italiana. Fra deicidio e persecuzioni» (Storicamente, No 7, 2011).

Meseguer, Manuel Nicolás, La intervención velada. El apoyo cinematográfico alemán al bando franquista (1936-1939) (Murcia, Universidad de Murcia, 2004).

Mirzroeff, Nicholas (ed.), Diaspora and Visual Culture: Representing Africans and Jews (Londres, Routledge, 2000).

ReHrmann, Norbert, «El síndrome de cenicienta: moros y judíos en la literatura española del siglo xIx y xx», en Gonzalo Álvarez Chillida y Ricardo Izquierdo Benito (coords.), El antisemitismo en España (Cuenca, Universidad de Castilla-La Mancha, 2007), pp. 207-235.

Rehrmann, Norbert, «Historia, literatura, identidad: El redescubrimiento de moros y sefardíes en la literatura española del siglo xix y principios del xx» (Raíces, $\mathrm{n}^{0} 36$, 1998), pp. 35-43.

-,El antisemitismo en España: la imagen del judío (1812-2012) (Madrid, Marcial Pons, 2002).

-, Das schwierige Erbe von Sefarad: Juden und Mauren in der spanischen Literatur. Von der Romantik bis zur Mitte des 20. Jahrhunderts (Frankfurt, Vervuert Verlagsgesellschaft, 2002)

Rосна, Carolina, "Jewish Self-Representations in Contemporary Argentine and Brazilian Films» (Journal of Modern Jewish Studies, nº 9 - 1, 2010), pp. 37-48. 
Rodríguez, Saturnino, El NO-DO catecismo social de una época (Madrid, Editorial Complutense, 1999).

RoHr, Isabelle, La derecha española y los judíos, 1898-1945. Antisemitismo y oportunismo (Valencia, PUV, 2010).

-, The Spanish Right and the Jews (1898-1945): Antisemitism and Opportunism (Sussex, Sussex Academic Press, 2007).

Rosenberg, Edgard, From Shylock to Svengali. Jewish Stereotypes in English Fiction (Stanford, Stanford University Press, 1960).

RotHer, Bernd, Franco y el Holocausto (Madrid, Marcial Pons, 2005).

Rozenberg, Danielle, L'Espagne contemporaine et la question juive (Toulouse, Presses universitaires du Mirail, 2006).

-, La España contemporánea y la cuestión judía (Madrid, Marcial Pons, 2010).

SALAH, Asher, «A imagem do judeu no cinema português», en Marina Pignatelli (coord.), Judeus e Cristãos Novos no Mundo Lusófono (Lisboa, Colibri, 2017), pp. 247-270

-, «Jews and Israel in Italian Cinema», en Italy 15oth Anniversary (Milano, Corriere della Sera Foundation, 2012), pp. 283-301.

-, «Maschere Giudaiche: gli ebrei al cinema italiano», en Italia Ebraica: oltre duemila anni di incontro tra la cultura italiana e l'ebraismo (Torino, Allemandi, 2007), pp. 221-235.

Sanchez-Biosca, Vicente, «Photography, Production Design, and Editing» en Jo Labanyi y Tatiana Pavlovic (eds.), A Companion to Spanish Cinema (Londres, Blackwell, 2013), pp. 345-369.

SAnz Ferreruela, Fernando, Catolicismo y cine en España (1936-1945) (Zaragoza, Institución Fernando el Católico, 2013).

Schreiberman, José, «El tema judío en la generación del 98», en Los judíos en la España contemporánea, historia y visiones, 1898-1998 (Cuenca, Universidad Castilla-La Mancha, 2000), pp. 61-74.

Shinan, Nitai, Qorbanot o Ashemim: Toledot Ha-Yehudim Be-Rei Ha-Historiografia Ha-Sefaradit Ba-Shanim 1759-1898 (Jerusalem, 2011).

Sмгтн, Paul Julian, «Representando a los otros: el cine y la televisión contemporánea», en España y Israel: veinte años después (Madrid, Librería-Editorial Dykinson, 2007), pp. 319-336.

TAL, Tzvi, «Seres queridos y objetos étnicos: judíos y palestinos en la comedia cinematográfica española» en España y Israel: veinte años después (Madrid, LibreríaEditorial Dykinson, 2007), pp. 215-223.

Touboul TARDIEu, Eva, Séphardisme et Hispanité. L'Espagne à la recherche de son passé (1920-1936) (París, 2009).

Tranche, Rafael R. y Sánchez-Bıosca, Vicente, No-Do. El tiempo y la memoria (Barcelona, Cátedra y Filmoteca española, 2001).

Vezyroglou, Dimitri, «Une chose et son contraire : le cinéma français et les ambiguïtés du philosémitisme en 1925», en M.-A. Matard-Bonucci (ed.), ANTISÉmythes; l'image des juifs entre culture et politique, 1848-1939, (París, Nouveau Monde éditions, 2005), pp. 207-216.

VIENne, Maité, «La sorcière : une histoire d’intolérance» (Cinémaction, $\mathrm{n}^{0}$ 92, 1999), pp. 48-54.

Vincenot, Emmanuel, «Alou, Said, Mihai et les autres : les immigrés dans le cinéma espagnol des années quatre-vingt-dix», en Nancy Berthier (ed.), Penser le cinéma espagnol (1975-200o), (Lyon, GRIMH/GRIMIA 2002), pp. 87-95. 
Wistrich, Robert Salomon, «La “otredad” judía en la historia europea: pasado y presente», en Silvina Shammah Gesser y Raanan Rein (co.), El otro en la España contemporánea/Prácticas, discursos, representaciones (Sevilla, Anfora, 2011), pp. $55-82$

Woods Peiró, Eva, White Gypsies: Race and Stardom in Spanish Musical Films (Minneapolis, University of Minnesota Press, 2012).

YSART, Federico, España y los judíos en la Segunda Guerra Mundial (Barcelona, Dopesa, 1973).

ZaAgsma, Gerben, Jewish Volunteers in the Spanish Civil War: A Case Study of the Botwin Company (London, 2001).

ZAPATA BARRERo, Ricard, «La reproducción del “otro” musulmán en España a través de prácticas sociales y reacciones políticas», en Silvina Shammah Gesser y Raanan Rein (co.), El otro en la España contemporánea/ Prácticas, discursos, representaciones) (Sevilla, Anfora, 2011), pp. 219-256.

Zimmermann, Moshe, Al Tigu Li Ba-Shoah: Hashpaat Ha-Shoah Ba-Qolnoa U-baHevrah Be-Israel (Haifa, 2002).

Zunzunegui, Santos, Los felices sesenta. Aventuras y desaventuras del cine español (1959-1971) (Barcelona, Paidós, 2005).

Recibido: 16 de julio de 2016

Aceptado para revisión por pares: 25 de octubre de 2016

Aprobado para publicación: 10 de marzo de 2017 